Latvijas Lauksaimniecības universitāte Latvia University of Agriculture

Meža fakultāte

Forest Faculty

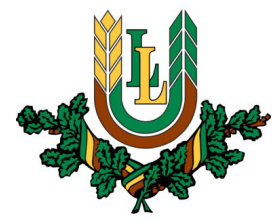

Mg.sc.ing. Andis Ābele

APSES (POPULUS TREMULA L.) KOKSNES GARENZĀG̣Ē ŠANAS ZĀG̣RIPU GRIEŽN̦U NODILUMS UN TĀ PROGNOZĒŠANA

\title{
ASPEN (POPULUS TREMULA L.) WOOD \\ LONGITUDINAL SAWING, RIPSAW BLADE CARBIDE TIP BLUNTNESS AND ITS PREDICTION
}

Promocijas darba KOPSAVILKUMS

Dr.sc.ing. zinātniskā grāda iegūšanai

SUMMARY

of the Doctoral thesis for the scientific degree of Dr.sc.ing. 
Promocijas darba zinātniskie vadītāji / Supervisors:

1. profesors / professor, Dr.habil.sc.ing., Dr.h.c.silv. Henn Tuherm

2. Dr.sc.ing. Mārtiņš Ernests Sleṇgóis

3. asociētais profesors / associate professor, Dr.sc.ing. Edgars Bukšāns

Promocijas darbs izstrādāts Latvijas Lauksaimniecības universitātes Meža fakultātes Kokapstrādes katedrā laika periodā no 2012. līdz 2016. gadam.

The Doctoral thesis is designed at the Latvia University of Agriculture, Forest faculty, Department of Wood Processing in period from 2012 till 2016.

Oficiālie recenzenti / Official reviewers:

1. Dr.habil.chem. Gaļina Teliševa - Latvijas Valsts Koksnes k̦īmijas institūta vadošā pētniece, Latvijas Zinātnes padomes eksperte / lead researcher of Latvian State Institute of Wood Chemistry, expert of the Latvian Council of Science;

2. Dr.sc.ing. Ramūnas Tupčiauskas - Latvijas Valsts Koksnes ķīmijas institūta pētnieks, Latvijas Zinātnes padomes eksperts / researcher of Latvian State Institute of Wood Chemistry, expert of the Latvian Council of Science;

3. PhD Regino Kask - Igaunijas Dzīvības zinātņu universitātes asociētais profesors / associate professor of Estonian University of Life Sciences.

Promocijas darba aizstāvēšana notiks Latvijas Lauksaimniecības universitātes Mežzinātnes nozares un Materiālzinātnes nozares Koksnes materiāli un tehnologijas apakšnozares promocijas padomes atklātā sēdē 2017. gada 25. augustā pulksten 10.00 Dobeles ielā 41, Jelgavā.

The Doctoral thesis will be present for public criticism in an open session of the Promotion Council of Wood Materials and Technology sub brunch of Forest Sciences and Material Sciences brunch of Latvia University of Agriculture held on August 25, 2017 at 10.00 a.m. in Dobeles iela 41, Jelgava.

Promocijas darbs ir pieejams Latvijas Lauksaimniecības universitātes Fundamentālajā bibliotēkā Lielā ielā 2, Jelgavā vai http://llufb.llu.lv/promoc_darbi.html.

The Doctoral thesis is available at the Fundamental Library of Latvia University of Agriculture, Lielā iela 2, Jelgava or http://llufb.llu.lv/promoc_darbi.html.

Atsauksmes sūtiet Promocijas padomes sekretārei S. Berņikovai-Bondarei, Dobeles iela 41, Jelgava, LV-3001, Latvija vai sarmite.bernikovabondare@llu.lv.

References are welcome to be sent to the secretary of the Promotion Council S. Bernikova-Bondare, Dobeles iela 41, Jelgava, LV-3001, Latvia or sarmite.bernikova-bondare@llu.lv.

ISBN 978-9984-48-267-5 (online) 


\section{SATURS / TABLA OF CONTENT}

\section{PROMOCIJAS DARBA APROBĀCIJA / APPROBATION OF DOCTORAL}

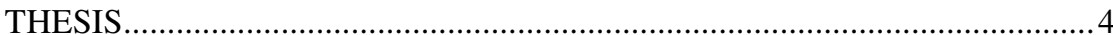

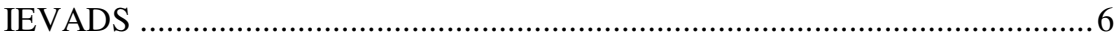

Promocijas darba tēmas aktualitāte ............................................................... 6

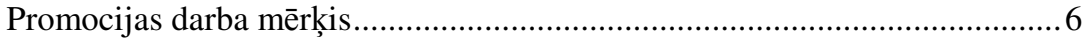

Promocijas darba pētnieciskie uzdevumi .......................................................

Promocijas darbā izmantotie materiāli un metodes ....................................... 7

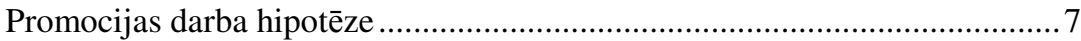

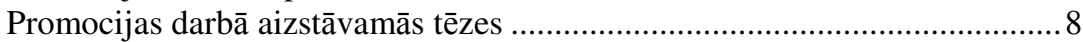

Promocijas darba zinātniskā novitāte.......................................................... 8

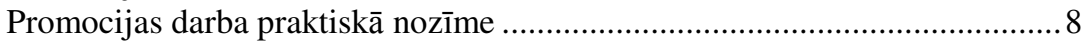

Promocijas darba struktūra ..................................................................... 8

1. KOKSNES GRIEŠANAS PROCESU IZZINĀTĪBAS ANALİZE................9

2. MATERIĀLI UN METODIKA …............................................................ 10

3. REZULTĀTI UN TO ANALİZE ............................................................. 12

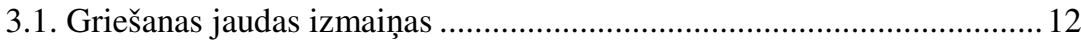

3.2. İpatnējā griešanas darba (spēka) izmainas ............................................. 18

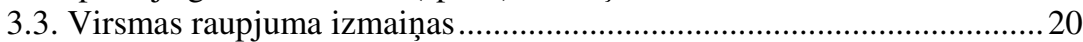

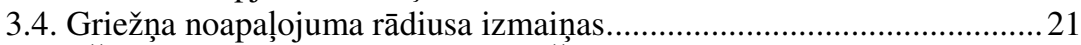

4. GRIEŽNUU NODILUMA PROGNOZËŠANA ........................................... 26

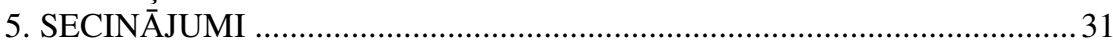

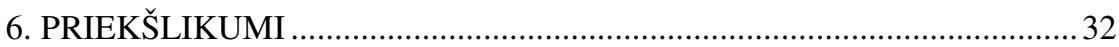

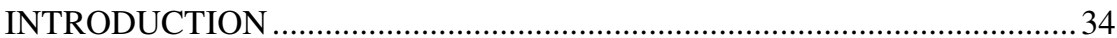

Topicality of subject of doctoral thesis ....................................................... 34

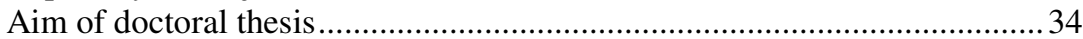

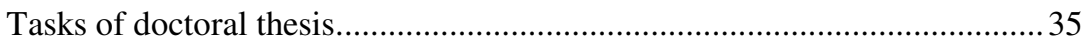

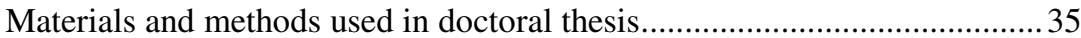

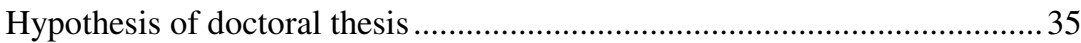

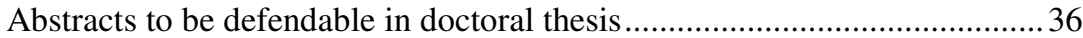

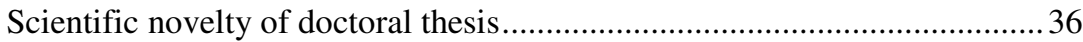

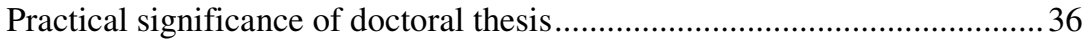

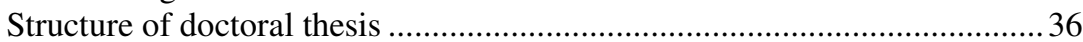

1. ANALYZE OF WOOD CUTTING PROCESSES …..................................... 37

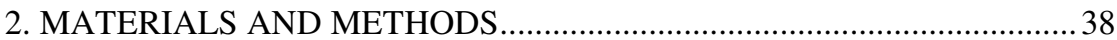

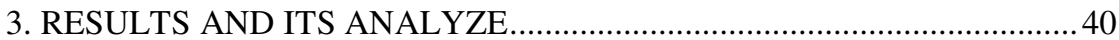

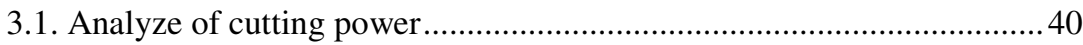

3.2. Analyze of specific cutting work (force) .............................................. 44

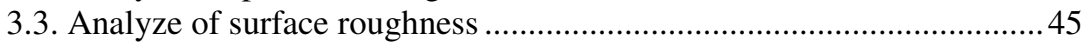

3.4. Analyze of roundness of the cutting edge ...............................................46

4. PREDICTION OF CARBIDE TIP BLUNTNESS ….................................. 48

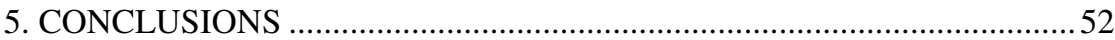

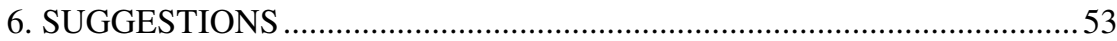




\section{PROMOCIJAS DARBA APROBĀCIJA / \\ APPROBATIONOF DOCTORAL THESIS}

\section{Publikācijas par promocijas darba tēmu /}

Scientific publications related to the subject of doctoral thesis

1. Ābele A., Tuherm H. (2016) Predictions of cutting tool wear of straight milled aspen wood with Taylor's equation. British Journal of Applied Science \& Technology, Volume 14, Issue 5, p. 1-7.

2. Ābele A., Tuherm H. (2014) Relationship between mechanical and electric cutting power at longitudinal sawing. In: Annual 20th International Scientific Conference Proceedings „Research for Rural Development 2014”, Volume 2, May 21-23, 2014, Jelgava, Latvia. Jelgava: LLU, p. 116-121.

3. Ābele A., Tuherm H. (2014) Griešanas spēks un jauda koksnes garenzāgé̄ěanā. No: Zinātniski praktiskā konference „Zinātne un prakse nozares attīstībai”: veltīta augstākās mežizglītības 95. un Meža fakultātes 75. gadskārtai: tēzes, 2014. gada marts, Jelgava, Latvija. Sastādīja L. Līpiņš. Jelgava: LLU, 72-75. lpp.

4. Tuherm H., Ābele A. (2014) Koksnes griešanas procesi: mācību līdzeklis LLU Meža fakultātes studentiem un nozares speciālistiem. Jelgava: Latvijas Lauksaimniecības universitāte, Meža fakultāte. Studentu biedrība „Šalkone”. 90 lpp.

5. Ābele A., Miončinskis U., Tuherm H. (2013) Determination of cutting tool wear and surface roughness of straight milled aspen wood. Pro Ligno, Volume 9, Number 4, p. 751-759.

6. Ābele A., Miončinskis U., Tuherm H. (2013) Determination of cutting tool wear and surface roughness of straight milled aspen wood. In: Proceedings of the 9th International Conference "Wood Science and Engineering in the Third Millennium" (ICWSE 2013), Part 2, November 7-9, 2013, Brasov, Romania. Brasov: Transilvania University, p. 759-766.

7. Ābele A., Tuherm H. (2013) Research methodology of cutting processes of aspen wood. In: Annual 19th International Scientific Conference Proceedings „Research for Rural Development 2013”, Volume 2, May 15-17, 2013, Jelgava, Latvia. Jelgava: LLU, p. 88-94. 
8. Ābele A., Miončinskis U., Tuherm H. (2013) Wear phases of cutting tool when milling aspen wood. In: Proceedings of the 9th Meeting of the Northern European Network for Wood Science and Engineering (WSE). September 11-12, 2013, Hannover, Germany. Hannover: Leibniz University Hannover, Faculty of Architecture and Landscape Sciences, p. 263.

9. Ābele A., Miončinskis U. (2012) Parameter changes which characterize the wear of the cutting tool in the milling process of aspen wood. Pro Ligno, Volume 8, Number 3, p. 74-88.

\section{Referāti zinātniskajās konferencēs par promocijas darba tēmu / Reports related to the subject of doctoral thesis at the scientific conferences}

1. Ābele A., Tuherm H. (2014) Relationship between mechanical and electric cutting power at longitudinal sawing, Annual 20th International Scientific Conference Research for Rural Development 2014, Latvia University of Agriculture, Jelgava, Latvia, May 21-23.

2. Ābele A., Tuherm H. (2014) Griešanas spēks un jauda koksnes garenzāgeěšanā. Zinātniski praktiskā konference „Zinātne un prakse nozares attīstībai", LLU, Meža fakultāte, Jelgava, 24.-27. marts.

3. Ābele A., Miončinskis U., Tuherm H. (2013) Determination of cutting tool wear and surface roughness of straight milled aspen wood, The 9th International Conference "Wood Science and Engineering in the Third Millennium” (ICWSE 2013), Transilvania University, Brasov, Romania, November 7-9.

4. Ābele A., Miončinskis U., Tuherm H. (2013) Wear phases of cutting tool when milling aspen wood, 9th Meeting of the Northern European Network for Wood Science and Engineering (WSE), Leibniz University Hannover, Hannover, Germany, September 11-12.

5. Ābele A., Tuherm H. (2013) Optimization of cutting regimes in longitudinal sawing of aspen wood, Annual 19th International Scientific Conference Research for Rural Development 2013, Latvia University of Agriculture, Jelgava, Latvia, May 15-17.

6. Ābele A., Tuherm H. (2013) Koksnes griešanas procesu pētījumu metodologijija. Zinātniski praktiskā konference „Zinātne un prakse nozares attīstībai”, LLU, Meža fakultāte, Jelgava, 18.-21. marts.

7. Ābele A., Miončinskis U., Tuherm H. (2012) Griežņa nodiluma izmaiņas, frēzējot apses koksni. Zinātniski praktiskā konference „Zinātne un prakse nozares attīstībai”, LLU, Meža fakultāte, Jelgava, 12.-15. marts. 


\section{IEVADS}

\section{Promocijas darba tēmas aktualitāte}

Kokapstrādes uzṇēmumos aizvien vairāk apstrādā mīksto lapkoku koksni, izgatavojot ne tikai apdares materiālus, bet arī būvkonstrukciju elementus un mēbeles. Nozīmīgākais koksnes mehāniskās apstrādes paņēmiens, kuru izmanto jebkura koksnes izstrādājuma izgatavošanas tehnologiskajā procesā, ir zāgeěšana. Turklāt no visiem koksnes griešanas procesiem, kuri pamatojas uz zāgê̌šanas principu, visizplatītākā, apstrādājot zāğmateriālus, ir tieši garenzāgeēšana ripzāǵmašīnās. Pētījumi, kuru mērķis ir griešanas režīmu noteikšana ne tikai garenzāgeěšanas, bet arī citos procesos, galvenokārt veikti, apstrādājot skujkoku un cieto lapkoku koksni. Tas izskaidrojams ar to, ka mīksto lapkoku koksne sākotnēji ir tikusi uzskatīta par mazvērtīgu un mehāniskajai apstrādei nepiemērotu, kā rezultātā ar to šādi pētījumi veikti nepietiekamā apjomā gan Latvijā, gan arī citās valstīs. Līdz ar to pašreizējā mīksto lapkoku koksnes apstrāde pamatojas uz likumsakarībām, kas iegūtas skujkoku un cieto lapkoku koksnes griešanas procesos. Tas rada nepieciešamību izstrādāt optimālus griešanas režīmus un griežņu nodiluma prognozēšanas paņēmienus tieši mīksto lapkoku koksnes garenzāg̊ēěanas procesam, jo paredzams, ka šo koku sugu koksnes izmantošana tikai palielināsies.

Viens no Latvijā ražotajiem specifiskajiem koksnes produktiem, kura sagatavju garenzāgeěšanas procesi šobrīd vēl nav pētīti un kura ražošanā būtu iespējams izmantot mīksto lapkoku sugu koksni ir koksnes šūnveida materiāls. Koksnes šūnveida materiālu ražošanā tradicionāli tiek izmantota skujkoku koksne, kuru atjaunošanās periods ir lielāks, salīdzinot ar mīksto lapkoku sugu koksni. Turklāt par skujkoku koksnes resursu pieejamību ir jākonkurē arī ar citu produktu ražotājiem. No mīksto lapkoku sugām tieši apses koksne varētu būt potenciāls izejmateriāls koksnes šūnveida materiālu ražošanai, ievērojot šīs sugas koksnes pieejamos resursus un to atjaunošanās spējas.

\section{Promocijas darba mērḳis}

Noskaidrot griežņu nodilumu ietekmējošos griešanas režīma faktorus un to likumsakarības, apstrādājot apses koksni ar garenzāgeěšanas pan̄ēmienu, kā arī izstrādāt metodi griežņu nodiluma prognozēšanai. 


\section{Promocijas darba pētnieciskie uzdevumi:}

1. analizēt informāciju par koksnes griešanas procesu, griežņu nodilumu un tos raksturojošajiem rādītājiem;

2. izpētīt garenzāǵěšanas procesa rezultatīvo rādītāju izmaiņas atkarībā no griešanas režīma parametriem;

3. noteikt analizēto un izpētīto faktoru ietekmi uz griežņu nodilumu un to likumsakarības;

4. izstrādāt metodi griežņu nodiluma iepriekšējai prognozēšanai atkarībā no to ietekmējošajiem griešanas režīma parametriem.

\section{Promocijas darbā izmantotie materiāli un metodes}

Griešanas procesu eksperimentālie darbi ir veikti ar programmvadības darbmašīnu Biesse Rover 325, kurā nostiprinātas speciālas konstrukcijas zāǵripas ar diviem griežņiem. Datu iegūšanai izmantoti elektroniskie mērinstrumenti: datu reǵistrētājs PicoLog ADC-20, spēka sensori Measurement specialities FC2211, strāvas stipruma datu registrētājs PicoLog CM3 un sensori Pico TA138, virsmas raupjuma mērīšanas ierīce Mahr Perthometer M2.

Eksperimentos apses koksnes sagatavēs iezāǵējumi izdarīti atbilstoši koksnes šūnveida materiālu sagatavju apstrādē lietotajai tehnologijai. Griešanas režīmu parametru ietekme uz griežņu nodilumu, griešanas jaudu, griešanas spēku un apstrādātās koksnes virsmas raupjumu noteikta, mainot atsevišķus griešanas režīma parametrus - griešanas ātrumu (rotācijas frekvenci), griežņa priekšējo leņ̧̧i (griežņa mugurleņķi), padeves ātrumu (padevi uz vienu griezni, skaidas biezumu) un iezāgeèjuma augstumu (leṇksi starp griešanas un padeves kustības virzienu).

Pētījumā iegūto datu matemātiskai apstrādei un grafiskai attēlošanai izmantota datorprogramma $M S$ Excel, bet attēlu veidošanai - AutoCAD, SolidWorks, CorelDRAW un Adobe Photoshop.

\section{Promocijas darba hipotēze}

Griešanas režīma parametriem - griešanas ātrumam (rotācijas frekvencei), griežņa priekšējam leņķim (griežņa mugurleņķim), padeves ātrumam (padevei uz vienu griezni, skaidas biezumam) un iezāgeèjuma augstumam (leņķim starp griešanas kustības virzienu un padeves kustības virzienu) - ir būtiska ietekme uz griešanas procesa rezultatīvajiem rādītājiem - griežņu nodilumu, griešanas jaudu, griešanas spēku, apstrādātās koksnes virsmas raupjumu. 


\section{Promocijas darbā aizstāvamās tēzes:}

1. atsevišķo griešanas procesa rezultatīvo rādītāju izmaiņu raksturs attiecībā pret griešanas trajektorijas garumu ir savstarpēji līdzvērtīgs;

2. zāğripu griežņu nodilumu ir iespējams prognozēt, identificējot citu rezultatīvo rādītāju un to ietekmējošo faktoru likumsakarības;

3. pieļaujamais griešanas trajektorijas garums būtiski palielinās, lietojot griešanas režīmu, kura parametru vērtības ir optimālas.

\section{Promocijas darba zinātniskā novitāte}

1. Iegūti jauni dati par griešanas režīmu parametru ietekmi uz griešanas procesu un tā rezultatīivajiem rādītājiem.

2. Noteiktas likumsakarības starp griešanas režīmu parametriem un griežņu nodilumu, griešanas jaudu, griešanas spēku, apstrādātās koksnes virsmas raupjumu.

3. Izstrādāta, pilnveidota un aprobēta koksnes griešanas procesu pētī̌sanas metodika.

4. Pirmo reizi Latvijā izstrādāta griežņa nodiluma prognozēšanas metode, konstantes un koeficienti, kas pamatojas uz Teilora formulu.

\section{Promocijas darba praktiskā nozīme}

1. Izstrādātās griešanas režīmu sakarības ir izmantojamas koksnes šūnveida un citu materiālu sagatavju garenzāgeēěanas procesos.

2. Pamatojoties uz izstrādātajām Teilora formulas griežņu nodiluma sakarībām, ir iespējams prognozēt griežņu kritiskā nodiluma sākuma robežu (starpasināšanas perioda ilgumu).

3. Iegūtie dati par griešanas režīmu parametru ietekmi uz griešanas procesu un to raksturojošajiem rādītājiem ir publicēti starptautiski pieejamos izdevumos. Līdz ar to tie ir pieejami izmantošanai citu autoru pētījumiem, kā arī mācību grāmatu sagatavošanai.

\section{Promocijas darba struktūra}

Promocijas darbs ir strukturēts septiṇās nodaḷās:

1. „Koksnes griešanas procesu izzinātības analīze;

2. „Materiāli un metodika”;

3. „Rezultāti un to analīze”;

4. „Griežnu nodiluma prognozēšana”;

5. „Patērētās jaudas izmaksas”;

6. „Secinājumi”;

7. „Priekšlikumi”.

Promocijas darba 131 lpp. ir iekḷauti 48 attēli, 6 tabulas, 89 formulas un 112 izmantotās informācijas avoti. 


\section{KOKSNES GRIEŠANAS PROCESU IZZINĀTĪBAS ANALĪZE}

Nodaļā analizēta līdzšinējos pêtījumos noskaidrotā griešanas režīmu parametru ietekme uz griešanas procesu un tā rezultatīvajiem rādītājiem, galvenokārt pievēršot uzmanību griežņu nodilumam, griešanas jaudai, griešanas spēkam un apstrādātās koksnes virsmas raupjumam. Bez tam aplūkota arī griežņu nodiluma prognozēšanas iespēja un griežņu nodilumizturības pilnveidošanas pieredze. Analīzes rezultātā izdarīti šādi galvenie secinājumi:

1. griešanas procesa rezultatīvos rādītājus - griežņa nodilumu, griešanas jaudu un spēku, apstrādātās koksnes virsmas raupjumu - galvenokārt ietekmē tikai četri griešanas režīma parametri - griešanas ātrums, griežņa priekšējais leṇkis, padeves ātrums un iezāgeējuma augstums. Līdz ar to pētījums jāturpina analizējot tikai šos četrus parametrus;

2. pētījumi, kas raksturo griežña nodiluma periodu ilgumu, salīdzinoši nedaudz ir atrodami par koksnes garenfrēzēšanas griezējinstrumentiem, bet par koksnes garenzāǵgešanas procesa griezējinstrumentu nodiluma periodiem informācija nav atrodama. Tas nozīmē, ka pētījumi ir jāorganizē tā, lai būtu iespējams noteikt atsevišķo griežņa nodiluma periodu ilgumu;

3. griežņa nodiluma iepriekšējai prognozēšanai ir piemērota Teilora formula, bet tā ir izstrādāta metālapstrādes griešanas procesiem, kā rezultātā nav informācijas par tās konstanšu un koeficientu vērtībām attiecībā uz kokapstrādes griezējinstrumentu nodilumu. Turklāt Teilora formula ievēro tikai griešanas ātruma ietekmi, bet ir noskaidrots, ka griešanas procesu ietekmē arī citi rādītāji - galvenokārt griežņa leņķiskie parametri, padeves ātrums, skaidas biezums un iezāgeejuma augstums. Lai Teilora formulu varētu izmantot koksnes garenzāgeěšanas griezējinstrumentu griežñu ekspluatācijas ilguma prognozēšanai, ir nepieciešams noteikt tās konstantes un papildus ietekmējošo rādītāju koeficientus;

4. īpatnējā griešanas darba (spēka), kas ir svarīgs parametrs griešanas jaudas aprēksinos, noteikšanai izmantotā koeficienta, kas raksturo griežña nodilumu, vērtības neievēro visus nozīmīgākos griežņa nodilumu ietekmējošos faktorus, tādēḷ pētījumā nepieciešams rast risinājumu šī koeficienta aprēķināšanas metodes precizēšanai;

5. izmantojot griežņu kriogēnisko apstrādi, ir iespējams ievērojami palielināt to nodilumizturību (līidz pat četrām reizēm, salīdzinot ar kriogēniski neapstrādātu griezni), tomēr, ievērojot apstrādes darbietilpību un ilgumu, kā arī to, ka pēc griežņu asināšanas kriogēniskās apstrādes rezultātā iegūtās īpašības zūd, tā nevar konkurēt ar citiem nodilumizturības palielināšanas paņēmieniem - virsmas 
pārklājumu uzklāšanu un spirālveida konfigurācijas griezējšķautņu izveidošanu.

\section{MATERIĀLI UN METODIKA}

Pētījums ir veikts, pamatojoties uz individuāli izstrādātu metodiku.

1. Pētījumā lietoti apses (Populus tremula L.) koksnes paraugi, kuru biezums ir $28 \mathrm{~mm}$, platums - $98 \mathrm{~mm}$, bet garums $-450 \mathrm{~mm}$. Koksnes paraugu šķērsgriezuma izmēri atbilst koksnes šūnveida materiāla ražošanā izmantoto sagatavju izmēriem.

2. Eksperimentālo darbu veikšanai ir konstruētas speciālas zāgrripas (1. tabula).

1. tabula / Table 1

Zāǵripu parametri / Parameters of circular saws

\begin{tabular}{|c|c|}
\hline Parametrs / Parameter & Vērtība / Value \\
\hline $\begin{array}{l}\text { Griešanas aploces diametrs } D, \mathrm{~mm} / \\
\text { Diameter of cutting circumference } D, \mathrm{~mm}\end{array}$ & 120 \\
\hline Plātnes biezums $s, \mathrm{~mm} /$ Thickness of body $\mathrm{s}, \mathrm{mm}$ & 2 \\
\hline Iezāgēejuma platums $b, \mathrm{~mm} / \operatorname{Kerf}$ width $b, \mathrm{~mm}$ & 3 \\
\hline $\begin{array}{l}\text { Griežņa mugurleṇkis } \alpha \text {, grādi / } \\
\text { Clearance angle } \alpha \text {, degree }\end{array}$ & $35,30,25,20$ \\
\hline $\begin{array}{l}\text { Griežña asinājuma leņķis } \beta \text {, grādi / } \\
\text { Tool angle } \beta \text {, degree }\end{array}$ & 40 \\
\hline $\begin{array}{l}\text { Griežņa priekšējais leṇkis } \gamma \text {, grādi / } \\
\text { Rake angle } \gamma \text {, degree }\end{array}$ & $15,20,25,30$ \\
\hline $\begin{array}{l}\text { Griežņa radiālais mugurleņkisis } \alpha_{1} \text {, grādi / } \\
\text { Radial clearance angle } \alpha_{1} \text {, degree }\end{array}$ & 2 \\
\hline $\begin{array}{l}\text { Griežņa tangenciālais mugurleṇkis } \alpha_{2} \text {, grādi / } \\
\text { Tangential clearance angle } \alpha_{2} \text {, degree }\end{array}$ & 3 \\
\hline Griežņa augstums $h, \mathrm{~mm} /$ Tooth height $h, \mathrm{~mm}$ & 15 \\
\hline $\begin{array}{l}\text { Volframa karbīda } K 10 \text { griežņu skaits z / } \\
\text { Number of tips made of tungsten carbide } \mathrm{K} 10 \mathrm{z}\end{array}$ & 2 \\
\hline
\end{tabular}

3. Pētījumā veikti 13 atsevišķi eksperimenti, kuros katrā izmainīta kāda no galveno griešanas režìma parametru vērtībām: griešanas ātrums $\left(20,35,50,75 \mathrm{~m} \mathrm{~s}^{-1}\right)$, griežña priekšējais leņkis (1. tabula), padeves âtrums $\left(4,8,12,16 \mathrm{~m} \mathrm{~min}^{-1}\right.$, ekvivalents padevei uz griezni no 0.251 līdz $1.257 \mathrm{~mm})$, iezāgeèjuma augstums $(6,12,18,24 \mathrm{~mm}$, ekvivalents vidējam leṇkim starp griešanas un padeves kustības virzienu 18.2 līdz 36.9 grādi). Pārējie griešanas režīma parametri noteikti, pamatojoties uz šiem četriem galvenajiem parametriem. 
4. Zāgeēšana veikta ar padeves virzienu, kas vērsts griešanas virzienā, izdarot vienu otram blakus esošus gareniskus iezāgeèjumus pārmaiņus vienā un otrā koksnes parauga platajā skaldnē un atstājot $3 \mathrm{~mm}$ biezas sienas starp iezāgeējumiem, atbilstoši koksnes šūnveida materiāla sagatavju izzāgeēšanas shēmai.

5. Zāgēěanas laikā paraugus nostiprināja speciālas konstrukcijas ierīcē, kura paredzēta griešanas spēka noteikšanai (lai noteiktu no tā izrietošo mehānisko griešanas jaudu). Ierīce sastāv no divām platformām (viena pārvietojas horizontālā virzienā, bet abas kopā - vertikālā virzienā), zem kurām ir izvietoti pieci spēka sensori Measurement Specialities $F C 22$. Spēka sensoru datu saglabāšanai un apstrādei izmantots datu regíistrētājs PicoLog ADC-20 un datorprogramma PicoLog Recorder.

6. Griešanas mehānisma elektromotora patērētās elektriskās jaudas noteikšanai izmantoti fāzu sprieguma un līnijas strāvas stipruma mērījumi. Spriegums mērīts ar analogo un digitālo voltmetru, bet strāvas stiprums - ar sensoriem Pico TA138, datu reg̣istrētāju PicoLog CM3 un datorprogrammu PicoLog Recorder, kā arī digitālo tiešā slēguma ampērmetru Schneider Electric iAMP.

7. Griežņa griezējškşautnes rādiusa mērǐšanai izmantota nospieduma metode, iespiežot griezējšķautni svina plātnē un nospiedumus analizējot digitālajā gaismas mikroskopā Keyence VHX - 100K.

8. Apstrādātās koksnes parauga virsmas (iezāgeējuma sānu virsmas) raupjuma $R_{z}$ mērīšana veikta ar mērītāju Mahr Perthometer M2.

9. Iegūtie dati galvenokārt attiecināti pret griešanas trajektorijas garumu vienam zāǵripas grieznim, kas aprēḳināts ar šādām formulām:

$$
\begin{gathered}
L_{k}=\frac{l \cdot n \cdot l_{p}}{10^{6} \cdot u \cdot z} \cdot m_{i} \cdot m_{p}, \\
l=\frac{10^{3} \cdot u}{n \cdot z}+\frac{\pi \cdot D}{360} \arccos \left(1-\frac{2 \cdot H}{D}\right),
\end{gathered}
$$

kur $\quad L_{k}-$ kopējais griešanas trajektorijas garums, m;

$l$ - griešanas trajektorijas garums viena zāgrripas apgrieziena laikā, mm; $n$ - zāg̣ripas rotācijas frekvence, $\min ^{-1}$; $l_{p}$ - apstrādājamā koksnes parauga garums, mm;

$u$ - padeves ātrums, $\mathrm{m} \mathrm{min}^{-1}$;

$z$ - zāgrripas griežņu skaits;

$m_{i}$ - iezāôējumu skaits vienā koksnes paraugā $\left(m_{i}=10\right)$; 
$m_{p}$ - paraugu skaits;

$\pi$ - konstante, kas raksturo attiecību starp riņ̧̧a līnijas garumu un diametru $(\pi=3.14)$;

$D$ - zāğripas griešanas aploces diametrs, $\mathrm{mm}$;

$H$ - iezāgéjuma augstums, $\mathrm{mm}$.

10. Griešanas režīma parametru ietekme uz griešanas procesa rezultatīvajiem rādītājiem analizēta, izmantojot korelācijas, regresijas un kovariācijas metodi. Statistiskās hipotēzes pārbaudītas ar būtiskuma līmeni $\alpha=0.05$.

\section{REZULTĀTI UN TO ANALĪZE}

\subsection{Griešanas jaudas izmaiṇas}

Analizējot elektriskās jaudas $\left(N_{e l}\right)$ un mehāniskās griešanas jaudas $\left(N_{g r}\right)$ izmaiņas atkarībā no griešanas režīma galvenajiem parametriem, noskaidrots, ka patērētā jauda vienmērīgi palielinās visā griešanas trajektorijas garumā $(L)$. Eksperimentu sākumā $N_{e l}$ ir 1.11 reizes lielāka par $N_{g r}$, bet eksperimentu beigās šì attiecība ir 1.34. Tādējādi, mērot $N_{e l}$, nevar iegūt patieso griešanas jaudu, kas tieši izriet no griešanas spēka. Motora patērētā elektroenerğijas jauda ir tikai netiešs raksturotājs, bet tā ir salīdzinoši elementāri nosakāma. Pētījuma rezultāti norāda, ka griešanas režīma galvenajiem parametriem ir būtiska ietekme uz patērēto jaudu un tās mērījumus ir iespējams izmantot griežņa nodiluma kontrolei.

Visvairāk $(99.3 \%)$ no $N_{e l}$ izmaiņām atkarībā no griešanas ātruma $(v)$ izskaidro otrās pakāpes polinoma funkcija:

$$
N_{e l v}=1.459 \cdot 10^{-2} \cdot L-10.962 \cdot v+9.239 \cdot 10^{-2} \cdot v^{2}+382.541,
$$

kur $\quad N_{e l v}-$ elektriskā jauda atkarībā no griešanas ātruma vērtībām robežās no 20 līdz $75 \mathrm{~m} \mathrm{~s}^{-1}$, W;

$L$ - griešanas trajektorijas garums, $\mathrm{m}$;

$v$ - griešanas ātrums, $\mathrm{m} \mathrm{s}^{-1}$.

Hipervirsma (3.1. att.) ar varbūtību $P=99.9 \%$ norāda, ka $N_{e l}$ palielināsies par $1.459 \cdot 10^{-2}$ vienībām, ja $L$ palielināsies par vienu metru. Savukārt, ja $v$ palielināsies par vienu vienību diapazonā no 20 līdz $59 \mathrm{~m} \mathrm{~s}^{-1}, N_{e l}$ samazināsies par iepriekšējās vienas vienības izraisītās jaudas vērtības samazinājuma 
un $1.848 \cdot 10^{-1}$ summu. Turpretī, ja $v$ palielinās par vienu vienību diapazonā no 59 līdz $75 \mathrm{~m} \mathrm{~s}^{-1}, N_{e l}$ palielināsies par iepriekšējās vienas vienības izraisītās jaudas vērtības palielinājuma un $1.848 \cdot 10^{-1}$ summu. Rezultāti norāda, ka optimālais $v$, kas rada mazāko patēēēto jaudu, ir $59 \mathrm{~m} \mathrm{~s}^{-1}$.

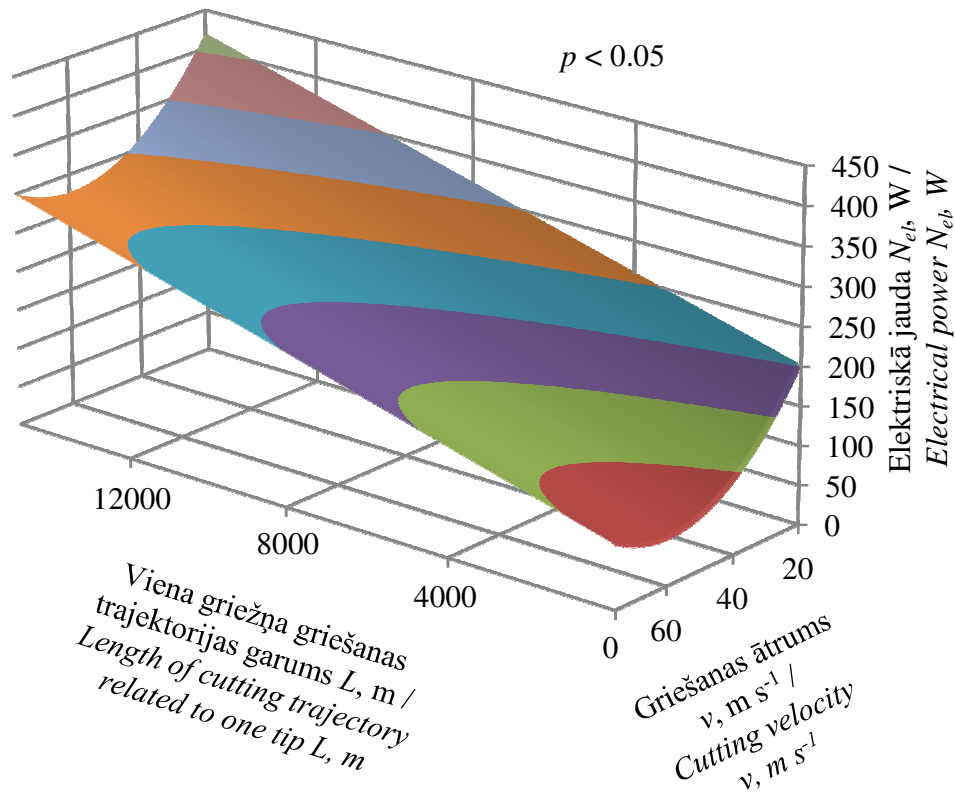

3.1. att. Elektriskās jaudas izmaiṇu hipervirsma atkarībā no griešanas trajektorijas garuma un griešanas ātruma.

Fig. 3.1. Hyper-surface of electrical power changes dependent on length of cutting trajectory and cutting velocity.

Regresijas analīze ar varbūtību $P=99.9 \%$ apstiprina būtisku $L$ un griežņa priekšējā leṇkşa $(\gamma)$ ietekmi uz $N_{e l}$ (3.2. att.), kuru raksturo šāda formula:

$$
N_{e l \gamma}=8.942 \cdot 10^{-3} \cdot L-4.058 \cdot \gamma+170.712,
$$

kur $\quad N_{e l \gamma}-$ elektriskā jauda atkarībā no griežņa priekšējā leņķa vērtībām robežās no 15 līdz 30 grādiem, W;

$L$ - griešanas trajektorijas garums, $\mathrm{m}$;

$\gamma$ - griežña priekšējais leņķ̧is, grādi. 


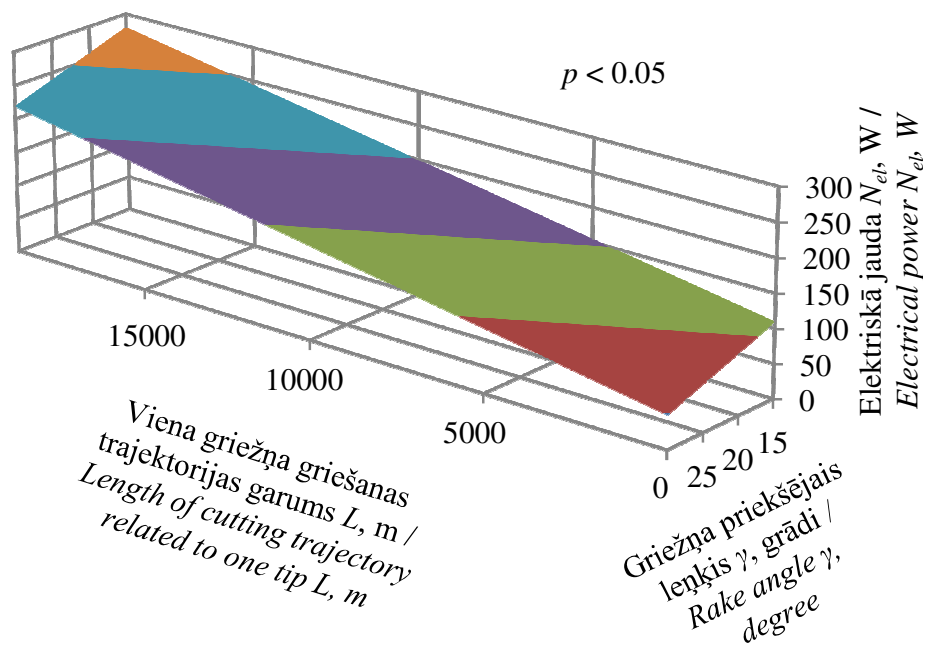

3.2. att. Elektriskās jaudas izmaiṇu hiperplakne atkarībā no griešanas trajektorijas garuma un griežņa priekšējā leṇksa. Fig. 3.2. Hyper-plane of electrical power changes dependent on length of cutting trajectory and rake angle.

Regresijas hiperplakne (3.2. att.) norāda, ka $N_{e l}$ palielinās, pieaugot $L$, kas izskaidrojams ar pakāpenisku griezējšksautnes noapaļojuma pieaugumu, kas pieaugoši ietekmē koksnes slāņa biezumu, kas grieznim ir jādeformē zem noapaļojuma rādiusa centra (lai deformētu biezāku koksnes slāni, ir nepieciešams lielāks darbs un līdz ar to arī jauda). Savukārt leņ̧̧̧a $\gamma$ ietekme uz $N_{e l}$ izpaužas tādējādi, ka $N_{e l}$ pieaug, ja leņksa $\gamma$ vērtība samazinās. Šāda ietekme izskaidrojama ar to, ka, samazinoties leņķim $\gamma$, griežņa priekšējā virsma tiecas uz paralēlu stāvokli attiecībā pret griešanas aploces rādiusvektoru un skaidas veidošanās zonā, kas atrodas virs griezējšķautnes noapalojuma rādiusa centra, pieaug skaidas elementa saliekuma pakāpe. Lai panāktu saliekuma pakāpi, kas tiecas šaurāka leņķa virzienā, ir nepieciešams pieaugošs darbs un jauda. Turklāt pieaugošs griežņa priekšējās plaknes vērsums samazina arī iespējamību, ka griežņa griezējšķautnes priekšā veidosies apsteidzoša koksnes mikroplaisāšana, kas pretējā gadījumā samazinātu koksnes pretestību. Tas nozīmēe ka garenzāgéēšanas procesos ir izdevīgi izvēlēties griezējinstrumentus ar lielāku leņķa $\gamma$ vērtību, jo tādējādi samazināsies patērētā jauda. Palielinot leṇki $\gamma$ no 15 līdz 20 grādiem, $N_{e l}$ samazinās par $17 \%$, palielinot no 20 līdz 25 grādiem, par $21 \%$, bet, palielinot no 25 līdz 30 grādiem, par $25 \%$. Savukārt, ja leņksi $\gamma$ palielina 
no 15 līdz 30 grādiem, elektriskā jauda samazinās līdz pat $42 \%$. Tomēr šāds jaudas samazinājums ir novērojams tikai griešanas procesa sākumā pirmajos 1000 griešanas trajektorijas garuma metros, jo parādās griežņa piestrādes nodiluma ietekme. Noteikts, ka, palielinoties $L$, procentuālā attiecība starp patēēto jaudu samazinās līdz griešanas procesa beigās (pēc $19000 \mathrm{~m} \mathrm{~L}$ sasniegšanas) iepriekšminētie procentuālie jaudas samazinājumi ir attiecīgi 7.25, 7.82, 8.49 un $17.8 \%$. Šāda pakāpeniski samazinoša leņķa $\gamma$ ietekme uz $N_{e l}$ atkarībā no $L$ liecina par to, ka griešanas procesa beigu posmā tiešā griezējšķautnes tuvumā ir izmainījušās griežņa leņkisko parametru vērtības, kuru cēlonis ir griežņa nolietojums kritiskā nodiluma periodā. Tādējādi turpmāka griežņa ekspluatācija pēc kritiskā griežņa nodiluma perioda sasniegšanas ir nevēlama ne tikai tādēl, ka samazinās kopējais griezējinstrumenta ekspluatācijas laiks, bet arī tādēl, ka samazinās leņķa $\gamma$ vērtība, kas mērīta tiešā griezējšķautnes tuvumā attiecībā pret giezējšķautnes noapalıjuma pieskarēm.

Padeves ātrums garenzāg̊ēšanas griešanas procesā ietekmē padevi uz griezni $\left(u_{z}\right)$, skaidas biezumu, $L$, kā arī slodzi, kas darbojas uz griezni un skaidu uzkrāšanas kapacitāti griežņstarpās. Turklāt $u_{z}$ ir vistiešākā ietekme uz griešanas spēku un jaudu, jo atšķirīgām padeves ātruma un zāǵripas rotācijas frekvences kombinācijām var būt mainīgs padeves ātrums, bet vienāda $u_{z}$, līdz ar to slodze, kas darbojas uz griezni, var būt nemainīga, mainoties padeves ātrumam. Padeves ātrums ir viens no griešanas režīma pamatparametriem, bet tas nav izdevīgs, lai salīdzinātu vairākus griešanas režīmus. Parametrs $u_{z}$ ir rādītājs, ar kuru var salīdzināt atšķirīgus griešanas režīmus. $N_{e l}$ izmaiņas atkarībā no $L$ un $u_{z}$ raksturo šāds daudzfaktoru regresijas vienādojums:

$$
N_{e l u_{z}}=1.353 \cdot 10^{-2} \cdot L-454.720 \cdot u_{z}+484.542 \cdot u_{z}^{2}+181.514
$$

kur $\quad N_{e l u_{z}}-$ elektriskā jauda atkarībā no padeves uz griezni vērtībām robežās no 0.251 līdz $1.257 \mathrm{~mm}, \mathrm{~W}$;

$L$ - griešanas trajektorijas garums, $\mathrm{m}$;

$u_{z}$ - padeve uz griezni, mm.

$N_{e l}$ izmaiņas atkarībā no $u_{z}$ neuzrāda viennozīmīgu ietekmi (3.3. att.). Ja $u_{z}$ palielinās par $0.001 \mathrm{~mm}$ diapazonā no $0.251 \mathrm{līdz} 0.471 \mathrm{~mm}$, tad $N_{e l}$ samazinās par iepriekšējās $u_{z}$ vienības izraisītās $N_{e l}$ samazinājuma un $9.691 \cdot 10^{-3}$ summu. Savukārt, $u_{z}$ izmainoties diapazonā no $0.471 \operatorname{līdz} 1.257 \mathrm{~mm}$, novērojama tieši pretēja reakcija $-N_{e l}$ palielinās par iepriekšêjās $u_{z}$ vienības $(0.001 \mathrm{~mm})$ izraisītās $N_{e l}$ pieauguma un $9.691 \cdot 10^{-3}$ summu. Tas nozīmē, ka optimālā $u_{z}$ vērtība, kura izraisa mazāko patērēto jaudu, ir $0.471 \mathrm{~mm}$. Šì $u_{z}$ vērtība pētījuma ietvaros atbilst padeves ātrumam $7.5 \mathrm{~m} \mathrm{~min}^{-1}$. 


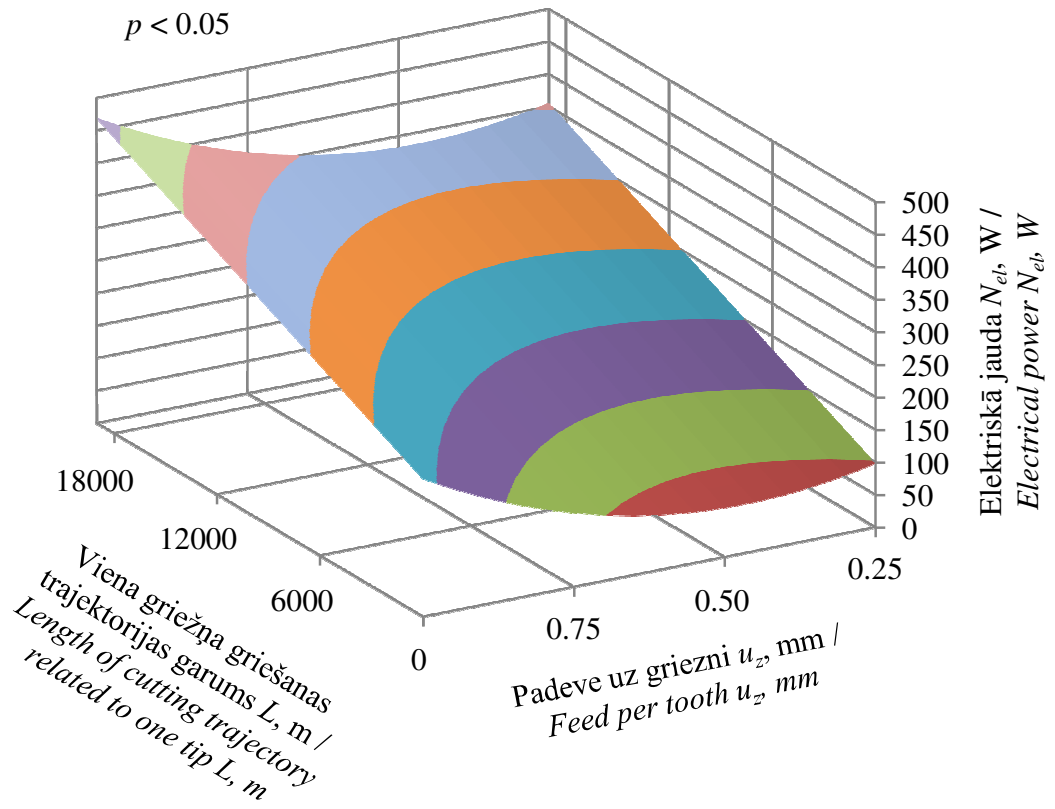

3.3. att. Elektriskās jaudas izmaiṇu hipervirsma atkarībā no griešanas trajektorijas garuma un padeves uz griezni.

Fig. 3.3. Hyper-surface of electrical power changes dependent on length of cutting trajectory and feed per tooth.

Iezāgeējuma augstuma ietekme uz griešanas procesu veikta, izmantojot vidējo leṇķi starp griešanas un padeves kustības virzienu $\left(\varphi_{\text {vid }}\right)$, jo tas vistiešāk raksturo griežņa un koksnes šķiedru virziena attiecību. Kaut arī iezāgéjuma augstums ir pozicionēts kā viens no galvenajiem griešanas režīma parametriem, tas tomēr ir jāuzskata kā iegūšanas parametrs leņkim $\varphi_{\text {vid }}$. Sakarību starp $N_{e l}, L$ un leņķi $\varphi_{\text {vid }}$ ar varbūtību $P=99.9 \%$ raksturo šāds lineārās daudzfaktoru regresijas vienādojums:

$$
N_{\text {el } \varphi_{v i d}}=8.687 \cdot 10^{-3} \cdot L+2.971 \cdot \varphi_{\text {vid }}+4.04 \cdot 10^{-1},
$$

kur $\quad N_{e l \varphi_{v i d}}-$ elektriskā jauda atkarībā no vidējā leņķa starp griešanas un padeves kustības virzienu vērtībām robežās no 18.2 līdz 36.9 grādi, W; 
$L$ - griešanas trajektorijas garums, m;

$\varphi_{\text {vid }}$ - vidējais leņķis starp griešanas un padeves kustības virzienu, grādi.

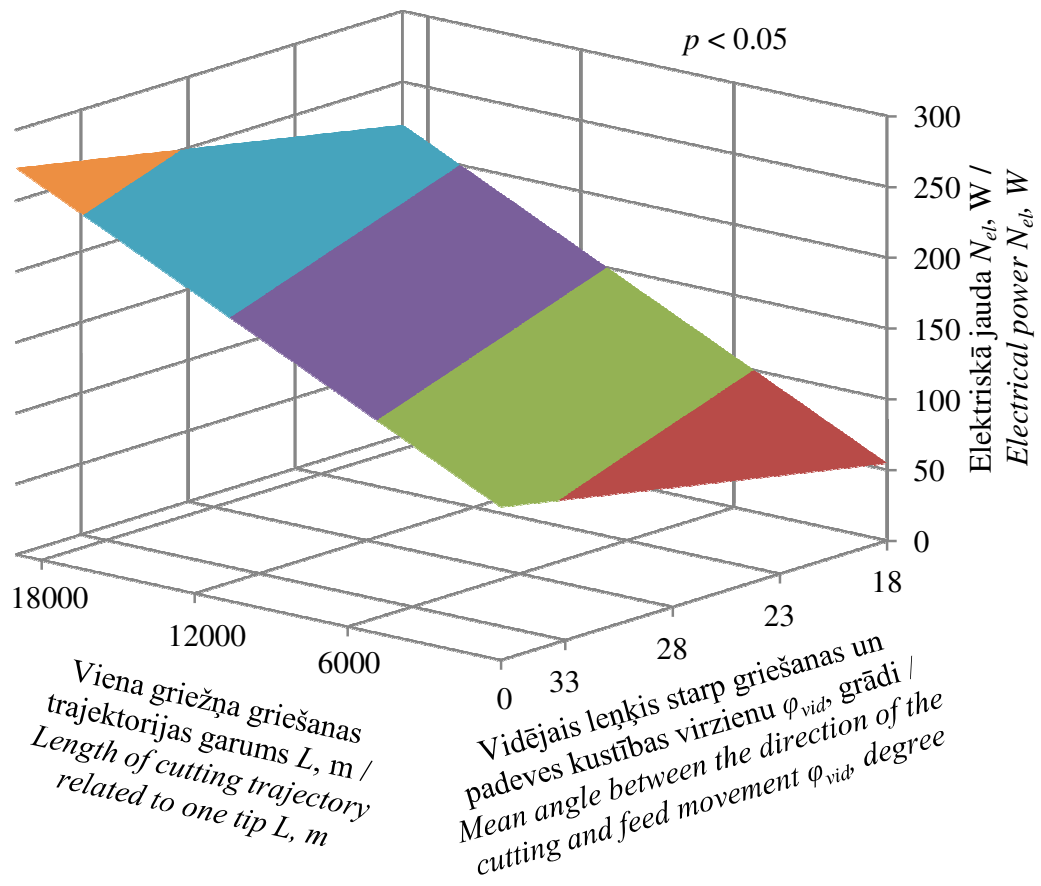

\section{4. att. Elektriskās jaudas izmaiņu hiperplakne atkarībā no griešanas trajektorijas garuma un vidējā leṇka starp griešanas un padeves kustības virzienu. Fig. 3.4. Hyper-plane of electrical power changes dependent on length of cutting trajectory and mean angle between the direction of the cutting and feed movement.}

Iepriekš raksturotie vienādojumi izskaidro $N_{e l}$ izmaiņas atkarībā no kāda galvenā vai atvasinātā griešanas režīma parametra $-v$, leņ̧̧a $\gamma, u_{z}$ un leņķa $\varphi_{\text {vid }}$. Analizējot šos vienādojumus, noskaidrots, ka pastāv būtiska ietekme uz $N_{e l}$. Līdz ar to var izvirzìt hipotēzi, ka pastāv būtiska visu četru griešanas režīma parametru vienlaicīga ietekme uz $N_{e l}$ izmaiņām atkarībā no $L$. Iegūstot šādu sakarību, ir iespējams aprēķināt $N_{e l}$ vērtību, kura atbilst perioda, kad jāveic griežņu asināšana, sākumam. Izvirzīto hipotēzi ar varbūtību 
$P=99.9 \%$ raksturo šāds regresijas vienādojums, kas izskaidro $80.5 \%$ no $N_{e l}$ izmaiņām:

$$
\begin{aligned}
N_{e l}= & 1.072 \cdot 10^{-2} \cdot L-6.750 \cdot v-5.989 \cdot 10^{-2} \cdot v^{2}-4.284 \cdot \gamma- \\
& -230.849 \cdot u_{z}+259.407 \cdot u_{z}^{2}+3.029 \cdot \varphi_{v i d}-2.235,
\end{aligned}
$$

kur $\quad N_{e l}-$ elektriskā jauda atkarībā no griešanas àtruma vērtībām robežās no 20 līdz $75 \mathrm{~m} \mathrm{~s}^{-1}$, griežņa priekšējā leṇka vērtībām robežās no 15 līdz 30 grādiem, padeves uz griezni vērtībām robežās no 0.251 līdz $1.257 \mathrm{~mm}$, un vidējā leņķa starp griešanas un padeves kustības virzienu vērtībām robežās no 18.2 līdz 36.9 grādi, W;

$L$ - griešanas trajektorijas garums, m;

$v$ - griešanas ātrums, $\mathrm{m} \mathrm{s}^{-1}$;

$\gamma$ - griežņa priekšējais leņķis, grādi;

$u_{z}$ - padeve uz griezni, mm;

$\varphi_{\text {vid }}$ - vidējais leņķis starp griešanas un padeves kustības virzienu, grādi.

Regresijas analīze norāda, ka ne galvenajiem griešanas režīma parametriem, ne arī to mijiedarbības efektam nav būtiskas ietekmes uz $N_{g r}$ atkarībā no $N_{e l}$. Līdz ar to $N_{g r}$ atkarību no $N_{e l}$ saista šāds lineārās regresijas vienādojums, kas ar varbūtību $P=99.9 \%$ izskaidro $86.7 \%$ no rezultatīvās pazīmes izmaiņām:

$$
N_{g r}=7.915 \cdot 10^{-1} \cdot N_{e l}-1.571,
$$

kur

$$
\begin{aligned}
& N_{g r}-\text { mehāniskā griešanas jauda, W; } \\
& N_{e l} \text { - elektriskā jauda, W. }
\end{aligned}
$$

\section{2. Īpatnējā griešanas darba (spēka) izmaiņas}

Griešanas jaudas aprēķināšanai svarīgs rādītājs ir īpatnējais griešanas darbs jeb īpatnējais griešanas spēks, kas raksturo darbu, kas nepieciešams, lai nogrieztu skaidu, kuras tilpums ir viens $\mathrm{cm}^{3}$. Otra izteiksme šim rādītājam ir saistīta ar griešanas spēka noteikšanu, kas raksturo spēku, kas nepieciešams, lai nogrieztu skaidu, kuras šķērsgriezuma laukums ir viens $\mathrm{mm}^{2}$. Ievērojot, ka viens $\mathrm{J} \mathrm{cm}^{-3}$ ir vienāds ar vienu $\mathrm{N} \mathrm{mm}^{-2}$, abas rādītāja izteiksmes izsaka viens 
un tas pats parametrs. Tātad, nosakot īpatnējo griešanas darbu $(K)$, vienlaikus tiks noteikts arī īpatnējais griešanas spēks, tādēḷ analizē var iekļaut tikai vienu no šiem rādītājiem. $K$ izmaiņas atkarībā no $L$ un griešanas režīma faktoriālajiem parametriem raksturo šādi daudzfaktoru regresijas vienādojumi:

$$
\begin{gathered}
K_{v}=1.448 \cdot 10^{-3} \cdot L-9.358 \cdot 10^{-1} \cdot v+7.857 \cdot 10^{-3} \cdot v^{2}+30.806, \\
K_{\gamma}=8.907 \cdot 10^{-4} \cdot L-2.897 \cdot 10^{-1} \cdot \gamma+12.202, \\
K_{u_{z}}=1.199 \cdot 10^{-2} \cdot L-6.825 \cdot u_{z}+2.791 \cdot 10^{-1} \cdot u_{z}^{2}+43.497, \\
K_{\varphi_{v i d}}=1.898 \cdot 10^{-3} \cdot L-1.489 \cdot \varphi_{v i d}+451.696,
\end{gathered}
$$

kur $\quad K_{v}-$ īpatnējais griešanas darbs atbilstoši griešanas ātruma vērtībām robežās no $20 \mathrm{līdz} 75 \mathrm{~m} \mathrm{~s}^{-1}, \mathrm{~J} \mathrm{~cm}^{-3}$; $K_{\gamma}$ - īpatnējais griešanas darbs atbilstoši griežņa priekšējā leņķ̧a vērtībām robežās no 15 līdz 30 grādiem, $\mathrm{J} \mathrm{cm}^{-3}$; $K_{u_{z}}$ - ippatnējais griešanas darbs atbilstoši padeves uz griezni vērtībām robežās no 0.251 līdz $1.005 \mathrm{~mm}, \mathrm{~J} \mathrm{~cm}^{-3}$; $K_{\varphi_{v i d}}$ - īpatnējais griešanas darbs atbilstoši vidējā leņķa starp griešanas un padeves kustības virzienu vērtībām robežās no 18.2 līdz 36.9 grādi, $\mathrm{J} \mathrm{cm}^{-3}$;

$L$ - griešanas trajektorijas garums, $\mathrm{m}$; $v$ - griešanas ātrums, $\mathrm{m} \mathrm{s}^{-1}$;

$\gamma$ - griežņa priekšējais leṇksis, grādi;

$u_{z}$ - padeve uz griezni, $\mathrm{mm}$;

$\varphi_{\text {vid }}$ - vidējais leņķis starp griešanas un padeves kustības virzienu, grādi.

$K$ analīzē iegūti šãdi secinājumi:

1. salīizinot mērǐšanas rezultātā iegūtās griešanas jaudas vērtības ar aprēkinātajām, var konstatēt, ka izmērītā jauda ir lielāka par aprēḳināto. Tas norāda uz trūkumiem esošajās aprēķinu formulās, jo $K$ noteikšanas formula ne tikai ierobežoti ievēro koksnes mehāniskās īpašības un blīvumu, bet arī griežņa nodilumu;

2. griežņa nodilums īpatnējā griešanas darba aprēkinināšanai tiek raksturots ar koeficientu $a_{\rho}$ atkarībā no griežņa darba ilguma, bet griežņa darba ilgums ir ļoti relatīvs rādītājs, jo tas ir atkarīgs no padeves ātruma - 
vienādā laika ilgumā, ja padeves ātrums ir atškirīgs, var tikt sasniegts atšķirīgs $L$ un līdz ar to arī atškirīgs griežņa nodilums;

3. $K$ vērtība konkrētos griešanas režīma apstākḷıs ir konstanta, tādēḷ tās palielināšanos atkarībā no $L$ izraisa griežņa nodiluma ietekme. Tas nozīmē, ka regresijas vienādojumā virziena koeficienta un $L$ reizinājums ir pielīdzināms koeficienta $a_{\rho}$ pieaugumam;

4. $K$ palielinās, ja $v$ samazinās no $50 \quad \overline{1} \mathrm{dz} \quad 20 \mathrm{~m} \mathrm{~s}^{-1}$ un palielinās no 50 līdz $75 \mathrm{~m} \mathrm{~s}^{-1}$. Pieaugums atkarībā no $L$ ir saistīts ar griežņa nodiluma pieaugumu, bet atkarībā no $v$ - ar zāgrripas dinamiskās stabilitātes samazināšanos;

5. $K$ lineāri palielinās visā pārbaudītajā leņķa $\gamma$ diapazonā no 15 līdz 30 grādiem;

6. padeve uz griezni $K$ ietekmē paraboliski - samazinoties $u_{z}, K$ palielinās, kas ir tieši pretēji $u_{z}$ ietekmei uz $N_{e l}$. Mazākā $K$ vērtība atbilst $u_{z}=0.471 \mathrm{lī} \mathrm{dz} 0.771 \mathrm{~mm}$;

7. $K$ pakāpeniski palielinās, ja palielinās $L$, bet samazinās leņķis $\varphi_{\text {vid }}$. Līdz ar to iezāgeéjuma augstuma ietekme, samazinot nogrieztās skaidas biezumu, uz $K$ ir būtiskāka par griešanas virziena attiecīibā pret koksnes šķiedru virzienu ietekmi.

\subsection{Virsmas raupjuma izmaiņas}

Nodaļā par virsmas raupjuma $\left(R_{z}\right)$ izmantošanu griežņa nodiluma prognozēšanai ir analizēta tikai len̦ksa $\gamma$ ietekme, jo pārējie galvenie griešanas režīma parametri neuzrādīja būtisku ietekmi uz virsmas raupjumu kopsakarībā ar griežņa nodilumu, kas izskaidrojams ar koksnes anizotropiju.

$R_{z}$ izmainuu analīzē iegūti šãdi secinājumi:

1. palielinoties leņkịm $\gamma$ no 15 līdz 30 grādiem, nebūtiski palielinās $R_{z}$ faktiskās vērtības, bet samazinās tā pieauguma intensitāte;

2. griežņa piestrādes nodiluma periodā $R_{z}$ palielinās ar intensitāti $5.326 \cdot 10^{-3} \mathrm{lī} \mathrm{dz} 5.888 \cdot 10^{-3} \mu \mathrm{m} \mathrm{m}^{-1}$, kas nav būtiski atkarīgs no leņķa $\gamma$;

3. griežņa monotonajā nodiluma periodā $R_{z}$ palielinās ar intensitāti $\quad 5.189 \cdot 10^{-4} \mathrm{lī} \mathrm{dz} 1.593 \cdot 10^{-3} \quad \mu \mathrm{m} \mathrm{m}^{-1}$, $\quad$ kas ir 3.6 līdz 11.3 reizes mazāks, salīdzinot ar piestrādes nodiluma periodu;

4. griežņa kritiskā nodiluma periodā $R_{z}$ palielinās ar intensitāti $1.061 \cdot 10^{-2}$ līdz $2.175 \cdot 10^{-2} \mu \mathrm{m} \mathrm{m}^{-1}$, kas ir 9.2 lìdz 41.9 reizes lielāka, salīdzinot ar monotonā nodiluma periodu, un 2.0 līdz 3.7 reizes lielāka, salīdzinot ar piestrādes nodiluma periodu; 
5. $R_{z}$ raksturlīkṇu un taišņu determinācijas koeficientu vērtības ir salīdzinoši mazas, kas saistīts ar koksnes anizotropiju. Tas nozīmē, ka ne vienmēr griežņa nodilumu ir iespējams izskaidrot tieši ar $R_{z}$ izmain̄ām. Rezultātā, kaut arī $R_{z}$ vienādojumi ir statistiski būtiski, tiem ir jāpiešksir tikai informatīva nozīme, bet nodiluma prognozēšanai jāizmanto griežņa noapalıjuma rādiusa izmaiņas.

\subsection{Griežņa noapaḷojuma rādiusa izmaiṇas}

Analizējot griežņa griezējšķautnes noapaļojuma rādiusa $\rho$ izmaiņas atkarībā no griešanas ātruma $\left(20 \mathrm{~m} \mathrm{~s}^{-1}\right)$, noskaidrots, ka piestrādes nodiluma periods ir $L$ robežās no 0 līdz tuvināti $900 \mathrm{~m}$ (3.5. att.), kas atbilst griešanas laikam tuvināti 10 minūtes. Rādiuss $\rho$ šajā periodā palielinās ar intensitāti $9.163 \cdot 10^{-3} \mu \mathrm{m} \mathrm{m}^{-1}$. Pēc tam rādiusa $\rho$ pieauguma intensitāte samazinās. Tas norāda, ka sākas griežņa monotonā nodiluma periods, kas turpinās līdz tuvināti $9700 \mathrm{~m}$ griešanas trajektorijas garuma sasniegšanai ar atbilstošo griešanas laiku 106 minūtes. Rādiuss $\rho$ šajā periodā palielinās ar intensitāti $3.314 \cdot 10^{-3} \mu \mathrm{m} \mathrm{m}^{-1}$ - griežņa noapaļojuma pieauguma intensitāte ir 2.76 reizes mazāka, salīdzinot ar piestrādes nodiluma periodu. Pēc monotonā griežņa nodiluma perioda beigām rādiuss $\rho$ atkal strauji palielinās, norādot par griežņa kritiskā nodiluma perioda sākšanos. Kritiskajā nodiluma periodā rādiuss $\rho$ palielinās ar intensitāti $9.685 \cdot 10^{-3} \mu \mathrm{m} \mathrm{m}^{-1}$ - griežņa noapaļojuma pieauguma intensitāte ir 2.92 reizes lielāka, salīdzinot ar monotonā nodiluma periodu, un 1.05 reizes lielāka, salīdzinot ar piestrādes nodiluma periodu.

Savukārt, ja griešanas ātrums ir $50 \mathrm{~m} \mathrm{~s}^{-1}$ piestrādes nodiluma periods ir $L$ robežās no 0 līdz tuvināti $1000 \mathrm{~m}$, bet griešanas laiks ir tuvināti 4.5 minūtes. Rādiuss $\rho$ šajā periodā palielinās ar intensitāti $7.623 \cdot 10^{-3} \mu \mathrm{m} \mathrm{m}^{-1}$. Pēc tam sākas monotonā nodiluma periods, kas turpinās līdz tuvināti 13100 m griešanas trajektorijas garuma sasniegšanas ar atbilstošo griešanas laiku 58.5 minūtes. Rādiuss $\rho$ šajā periodā palielinās ar intensitāti $2.298 \cdot 10^{-3} \mu \mathrm{m} \mathrm{m}^{-1}$ - griežņa noapalı̧ojuma pieauguma intensitāte ir 3.3 reizes mazāka, salīdzinot ar piestrādes nodiluma periodu. Kritiskais nodiluma periods sākas pēc tuvināti $13100 \mathrm{~m}$ griešanas trajektorijas garuma sasniegšanas, kurā rādiuss $\rho$ palielinās ar intensitāti $7.817 \cdot 10^{-3} \mu \mathrm{m} \mathrm{m}^{-1}$ - griežņa noapaļojuma pieauguma intensitāte ir 3.4 reizes lielāka, salīdzinot ar monotonā nodiluma periodu, un 1.03 reizes lielāka, salīdzinot ar piestrādes nodiluma periodu. 


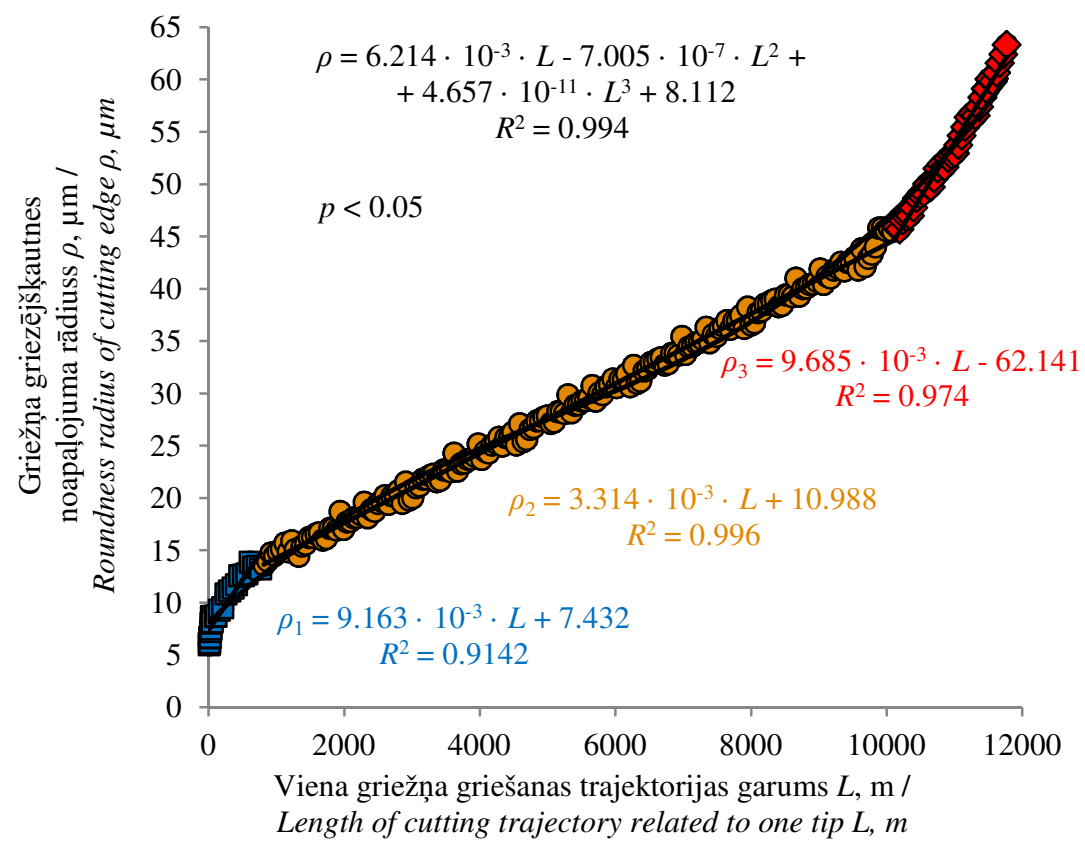

3.5. att. Griežņa griezējšķautnes noapaļojuma rādiusa izmaiņas atkarībā no griešanas trajektorijas garuma, ja griešanas ātrums ir $20 \mathrm{~m} \mathrm{~s}^{-1}$ :

Fig. 3.5. Changes of roundness radius of cutting edge dependent on length of cutting trajectory at cutting velocity $20 \mathrm{~m} \mathrm{~s}^{-1}$ :

- - griežņa piestrādes nodiluma periods / initial bluntness period;

- griežņa monotonā nodiluma periods / monotone bluntness period;

- griežņa kritiskā nodiluma periods / critical bluntness period.

Griešanas procesa sākumā rādiuss $\rho$ ir 4 līdz $5 \mu \mathrm{m}$, bet piestrādes nodiluma perioda beigās tas ir palielinājies nepilnas trīs reizes līdz $13 \ldots 14 \mu \mathrm{m}$. Savukārt, sākoties griežņa kritiskā nodiluma periodam, rādiuss $\rho$ ir palielinājies līdz $41 \ldots 43 \mu \mathrm{m}$ (3.6. att.). Salīdzinot rādiusa $\rho$ pieaugumu, var secināt, ka griešanas trajektorijas garums, sākoties kritiskajam nodilumam, ir atšķirīgs - palielinot griešanas ātrumu no 20 līdz $50 \mathrm{~m} \mathrm{~s}^{-1}$, kritiskā nodiluma sākuma robeža iestājas par $33.6 \%$ vēlāk. Analogisku sakarību uzrāda arī salīdzinājums starp griešanas âtrumu $20 \ldots 35 \mathrm{~m} \mathrm{~s}^{-1}$ un $35 \ldots 50 \mathrm{~m} \mathrm{~s}^{-1}$, bet starp griešanas ātrumu 50 un $75 \mathrm{~m} \mathrm{~s}^{-1}$ novērojams griešanas trajektorijas samazinājums (3.7 att.). Griešanas ātruma būtisko ietekmi uz griežņa nodilumu ar varbūtību $P=99.9 \%$ raksturo regresijas analīzes vienādojums (3.7. att.). 


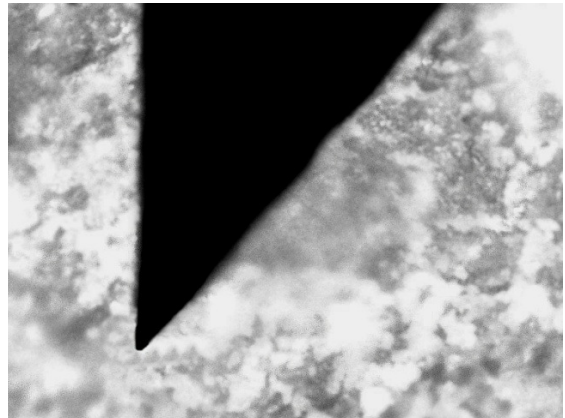

a

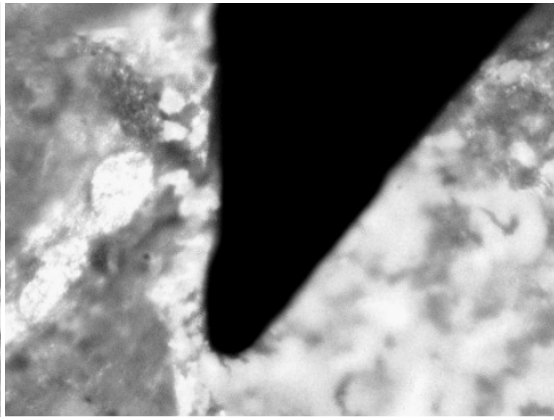

b

3.6. att. Griežņa griezējšksautnes profila nospiedumi svina plātnē (palielināti 800 reizes):

Fig. 3.6. Replicas of cutting edge in lead sheet (enlarged 800 times):

a - pirms griešanas procesa sākšanas / before beginning of the cutting process; $\mathrm{b}$ - pēc 19000 griešanas trajektorijas garuma metru sasniegšanas / after $19000 \mathrm{~m}$ of length of the cutting trajectory.

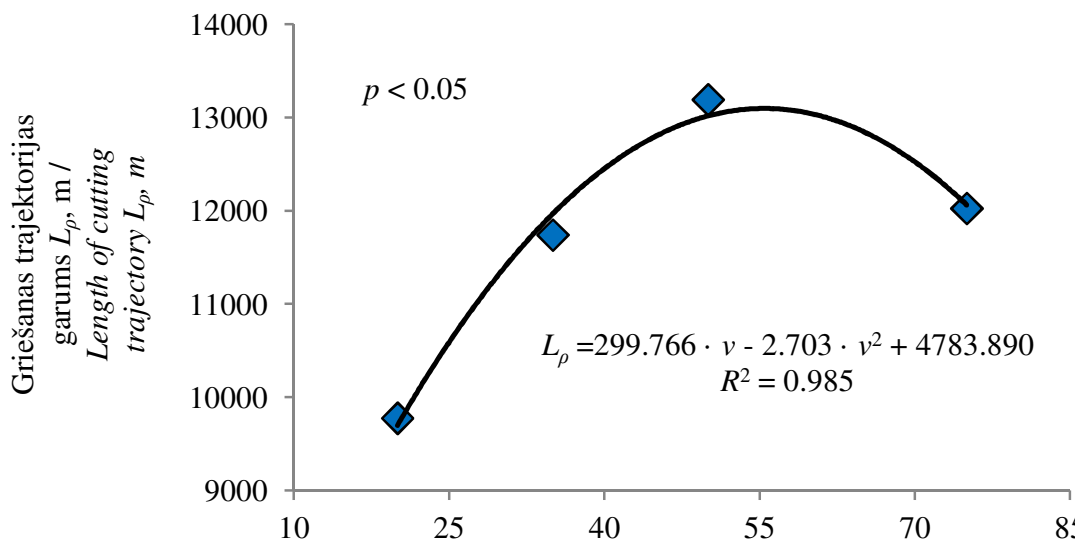

Griešanas ātrums $v, \mathrm{~m} \mathrm{~s}^{-1} /$ Cutting velocity $v, \mathrm{~ms}^{-1}$

3.7. att. Griežña kritiskā nodiluma sākumam atbilstošais griešanas trajektorijas garums atkarībā no griešanas ātruma.

Fig. 3.7. Length of cutting trajectory corresponding to start of critical bluntness period dependent on cutting velocity.

Noskaidrots, ka griežṇa priekšējais leṇksis kritiskā griežņa nodiluma sākuma robežu ietekmē lineāri. Palielinot leņķi $\gamma$ robežās no 15 līdz 20 grādiem, kritiskais griežņa nodilums sākas par $10 \%$ vēlāk 
attiecībā pret kritiskā nodiluma perioda sākuma robežu, ja leņ̧̧is $\gamma$ ir 15 grādi, un par $7 \%$ vēlāk, ja leṇki $\gamma$ palielina no 20 līdz 25 un no 25 līdz 30 grādiem attiecībā pret 20 un 25 grādu leņki. Tas apstiprina to, ka optimālais leņķis $\gamma$ ir 30 grādi, jo tādējādi pētījuma ietvaros ir ne tikai mazākā patērētā jauda, bet arī lielāks starpasināšanas perioda ilgums. Leņ̧̧a $\gamma$ ietekmes būtiskumu ar varbūtību $P=99.7$ \% raksturo regresijas analīzes vienādojums (3.8. att.).

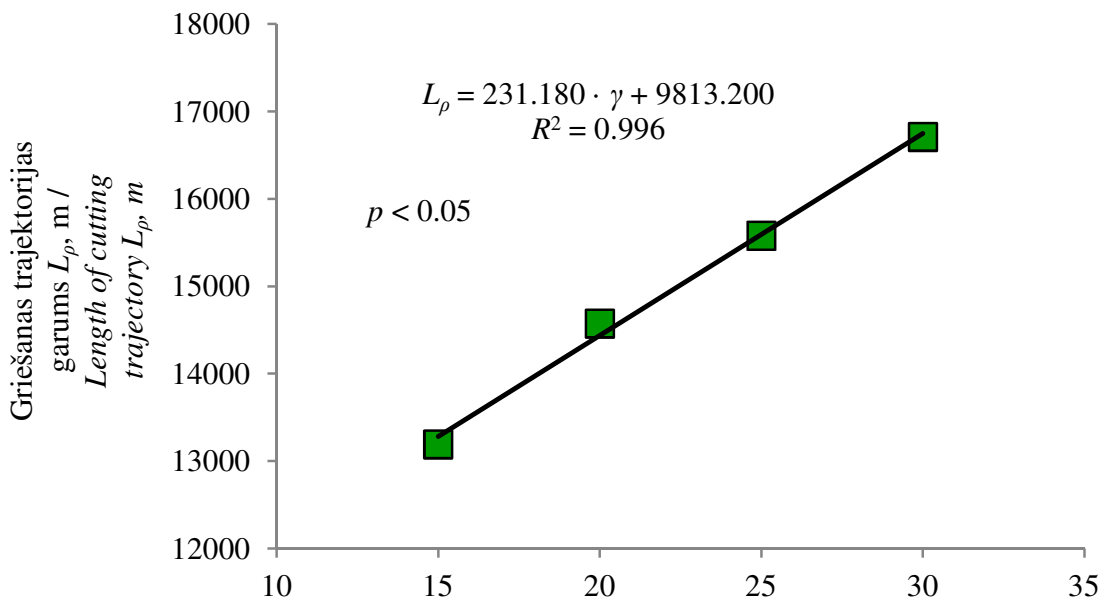

Griežņa priekšējais leņkis $\gamma$, grādi / Rake angle $\gamma$, degree

3.8. att. Griežņa kritiskā nodiluma sākumam atbilstošais griešanas trajektorijas garums atkarībā no griežņa priekšējā leņka.

Fig. 3.8. Length of cutting trajectory corresponding to start

of critical bluntness period dependent on rake angle.

Atbilstoši regresijai padeves kustības iedarbību raksturojošais rādītājs padeve uz griezni kritiskā griežña nodiluma sākuma robežu ietekmē lineāri. Šos rādītājus saista cieša negatīva korelācija $(r=0.976)$, kas nozīmē, ka, palielinoties $u_{z}$ vērtībām, kritiskā griežņa nodiluma sākuma robeža iestājas aizvien ātrāk, jo palielinās slodze uz griezni - grieznim vienādā laika periodā ir jānogriež pieaugošs koksnes tilpums. Palielinot $u_{z}$ robežās no 0.251 līdz $0.503 \mathrm{~mm}$, kritiskais griežņa nodilums sākas par 4.5 griešanas trajektorijas garuma procentiem ātrāk attiecībā pret kritiskā nodiluma perioda sākuma robežu, ja padeve uz griezni ir $0.251 \mathrm{~mm}$, par $10 \%$ âtrāk attiecībā pret $u_{z}=0.503 \mathrm{~mm}$, ja padevi uz griezni palielina no 0.503 līdz $0.754 \mathrm{~mm}$, un par $14 \%$ âtrāk attiecībā pret $u_{z}=0.754 \mathrm{~mm}$, ja $u_{z}$ palielina no 0.754 līdz $1.005 \mathrm{~mm}$. Padeves uz griezni ietekmes būtiskumu ar varbūtību $P=97.6 \%$ pierāda lineārās regresijas analīzes vienādojums (3.9. att.) 


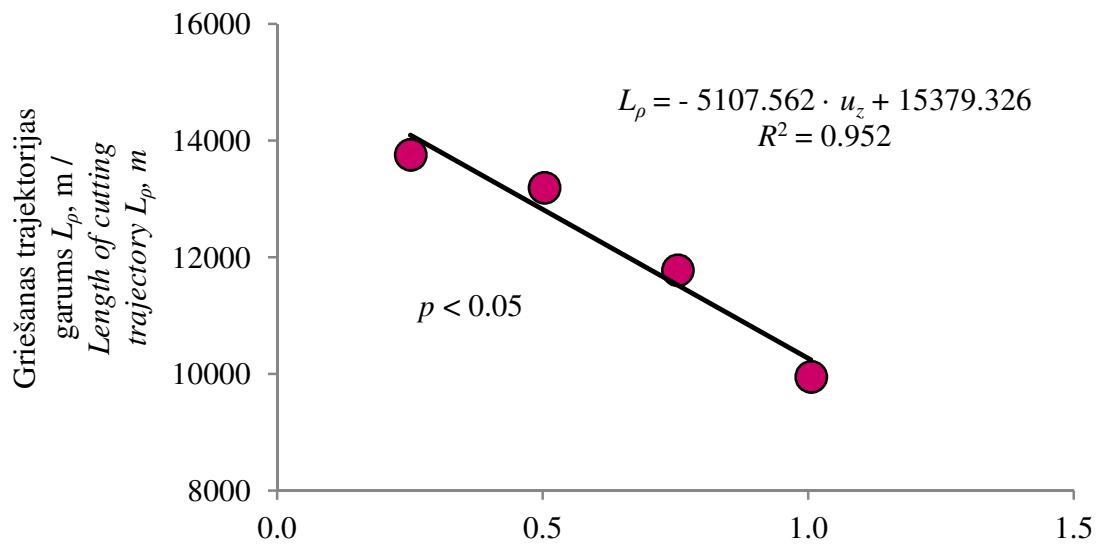

Padeve uz griezni $u_{z}, \mathrm{~mm} /$ Feed per tooth $u_{z}, \mathrm{~mm}$

3.9. att. Griežņa kritiskā nodiluma sākumam atbilstošais griešanas trajektorijas garums atkarībā no padeves uz griezni.

Fig. 3.9. Length of cutting trajectory corresponding to start of critical bluntness period dependent on feed per tooth.

Vidējā leṇķa starp griešanas un padeves kustības virzienu ietekmes uz griežņa kritiskā nodiluma sākuma griešanas trajektorijas garumu korelācijas analīze norāda par ciešu negatīvu sakarību $(r=0.987)$. Palielinoties leņķa $\varphi_{\text {vid }}$ vērtībām, kritiskā griežņa nodiluma sākuma robeža tiek sasniegta ātrāk. Izskaidrojums šādai parādībai ir analogisks $u_{z}$ ietekmei, jo abiem rādītājiem pieaugot, palielinās skaidas biezums un līdz ar to arī nogrieztās skaidas tilpums laika vienībā, kas palielina patērēto jaudu un veicina griežņa nolietošanos. Palielinot leṇki $\varphi_{\text {vid }}$ robežās no 18.2 līdz 25.8 grādiem, $L$ līdz kritiskā griežņa nodiluma sākumam samazinās par $6.5 \%$ attiecībā pret $L$, ja leņķis $\varphi_{\text {vid }}$ ir 18.2 grādi, par $7.1 \%$, ja leņķi $\varphi_{\text {vid }}$ palielina no 25.8 līdz 31.8 grādiem, un par $10.2 \%$, ja leņķi $\varphi_{\text {vid }}$ palielina no 31.8 līdz 36.9 grādiem. Leņ̧̧a $\varphi_{\text {vid }}$ būtiskumu ar varbūtību $P=98.7 \%$ pierāda lineārās regresijas analīzes vienādojums (3.10. att.).

Pamatojoties uz iegūtajām griešanas režīmu parametru būtiskajām sakarībām un griešanas trajektorijas garuma, kura sasniegšanas brīdī sākas griežņa kritiskā nodiluma periods, vērtībām, var secināt, ka rezultāti ir izmantojami griežņu nodiluma prognozēšanai, izmantojot Teilora formulu. 


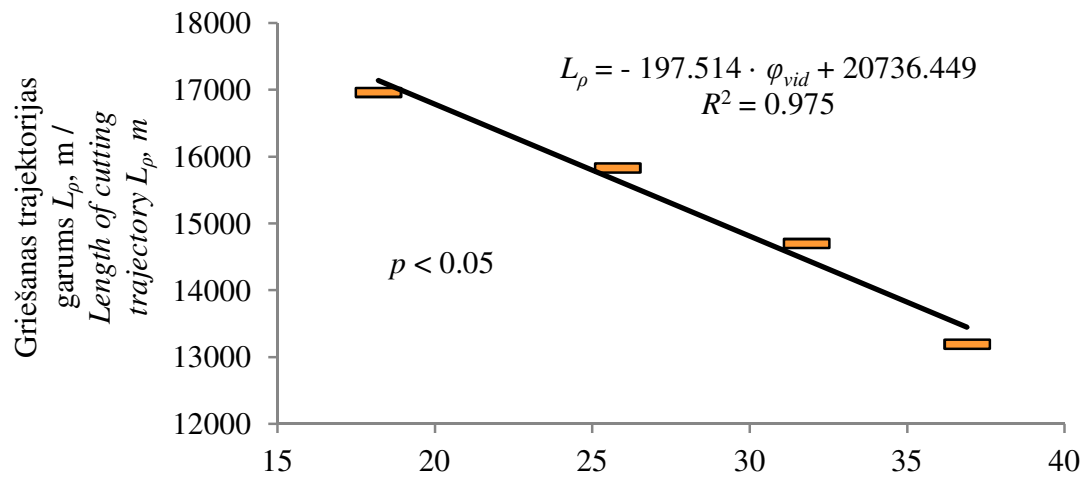

Vidējais leṇkis starp griešanas un padeves kustības virzienu $\varphi_{\text {vid }}$, grādi /

Mean angle between cutting and feed direction $\varphi_{\text {vid }}$, degree

3.10. att. Griežņa kritiskā nodiluma sākumam

atbilstošais griešanas trajektorijas garums atkarībā

no vidējā leṇka starp griešanas un padeves kustības virzienu.

Fig. 3.10. Length of cutting trajectory corresponding to start

of critical bluntness period dependent on mean angle between the direction of the cutting and feed movement.

\section{GRIEŽN̦U NODILUMA PROGNOZĒŠANA}

Koksnes griešanas procesu izzinātības analīzē noskaidrots, ka griežņu nodiluma prognozēšanu ir iespējams veikt, izmantojot Teilora formulu. Tomēr tajā ir nepieciešams ieviest modifikācijas, jo griežņu nodiluma prognozēšanai lietderīgāk ir izmantot $L$ nevis laiku, jo laiks ir atkarīgs no padeves ātruma:

$$
v \cdot L^{\psi}=C,
$$

jeb

$$
\ln v+\psi \cdot \ln L=\ln C,
$$

kur $\quad v$ - griešanas ātrums, $\mathrm{m} \mathrm{s}^{-1}$;

$L$ - griešanas trajektorijas garums, $\mathrm{m}$;

$\psi$ - konstante, kas atkarīga no griežņa ekspluatācijas ilguma funkcijas vērsuma attiecībā pret koordinātu sistēmas, kurā tā ir attēlota, asīm; 
C - konstante, kura ir vienāda ar naturāllogaritmu no griežņa ekspluatācijas ilguma funkcijas krustpunkta vērtības ar koordinātu sistēmas, kurā tā ir attēlota, ordinātu asi.

Savukārt konstanti $\psi$, ievērojot, ka pētījumā aplūkotajā $L$ diapazonā griežņa nodiluma izmaiņas ir inversas klasiskajai Teilora formulai (3.7. att.) un ka griešanas laiku var aizvietot ar $L$, var raksturot ar šādu vienādojumu:

$$
\psi_{i}=-1 \cdot \frac{\ln v_{1}-\ln v_{2}}{\ln L_{1}-\ln L_{2}},
$$

kur $\quad \psi_{i}-$ konstante, kas atkarīga no griežņa ekspluatācijas ilguma funkcijas vērsuma attiecībā pret koordinātu sistēmas, kurā tā ir attēlota, asīm atkarībā no i-tā griešanas ātruma diapazona; $v_{1} ; v_{2}$ - atšşirīịgas griešanas ātruma vērtības, $\mathrm{m} \mathrm{s}^{-1}$; $L_{1} ; L_{2}$ - griešanas trajektorijas garumi, kas atbilst griešanas ātrumiem attiecīgi $v_{1}$ un $v_{2}, \mathrm{~m}$.

Pētījuma rezultāti (3.7. att.) norāda, ka $v$ diapazonā no 20 līdz $35 \mathrm{~m} \mathrm{~s}^{-1}$ un no $35 \mathrm{līdz} 50 \mathrm{~m} \mathrm{~s}^{-1}$ griežņa nodilums raksturojas ar vienādu izmaiņu tendenci, tādēl šos diapazonus var apvienot. Pamatojoties uz 3.7. att., pię̧aujamais griešanas trajektorijas garums, sākoties kritiskajam nodiluma periodam, $L_{1}=9779 \mathrm{~m}$, ja griešanas ātrums $v_{1}=20 \mathrm{~m} \mathrm{~s}^{-1}$, un piel̦aujamais griešanas trajektorijas garums $L_{2}=13193 \mathrm{~m}$, ja griešanas ātrums $v_{2}=50 \mathrm{~m} \mathrm{~s}^{-1}$. Lìdz ar to konstante $\psi$ (4.3. formula):

$$
\psi_{v=20 \ldots 50}=-1 \cdot \frac{\ln 50-\ln 20}{\ln 13139-\ln 9779}=-3.060
$$

Analogiski aprēķināta koeficienta $\psi$ vērtība arī pārējam $v$ diapazonam:

$$
\psi_{v=50 \ldots 75}=-1 \cdot \frac{\ln 75-\ln 50}{\ln 12026-\ln 13193}=4.378
$$

Ievietojot rezultātus 4.2. formulā un aprēķinot naturāllogaritmu vienādojumus, iegūst, ka konstantes $C$ vērtības ir šādas:

$$
C_{v=20 \ldots 50}=e^{\ln 20+(-3.060) \cdot \ln 9779}=e^{\ln 50+(-3.060) \cdot \ln 13193}=1.233 \cdot 10^{-11}
$$




$$
C_{v=50 \ldots 75}=e^{\ln 50+4.378 \cdot \ln 13193}=e^{\ln 75+4.378 \cdot \ln 12026}=5.465 \cdot 10^{19}
$$

Līdz ar to, pamatojoties uz 4.1. formulu, Teilora formulas, kas atbilst pētījuma diapazonam ir šādas:

$$
\begin{aligned}
& v_{20 \ldots 50} \cdot L^{-3.060}=1.233 \cdot 10^{-11} \\
& v_{50 \ldots .75} \cdot L^{4.378}=5.465 \cdot 10^{19}
\end{aligned}
$$

Formulas (4.4. un 4.5.) raksturo griešanas trajektorijas garumu (griežņa nodilumu) tikai atkarībā no $v$, tomēr, veicot koksnes griešanas procesu izzinātības analīzi un iegūto griežņa nodiluma sakarību novērtējumu, secināts, ka arī pārējiem galvenajiem griešanas režīma parametriem ir būtiska ietekme. Pārējo parametru ietekmi raksturo šāda papildinātā Teilora formula:

$$
v \cdot L^{\psi} \cdot \gamma^{f} \cdot u_{z}^{\kappa} \cdot \varphi_{v i d}^{g}=C,
$$

kur $\quad v$ - griešanas ātrums, $\mathrm{m} \mathrm{s}^{-1}$;

$L$ - griešanas trajektorijas garums, m;

$\gamma$ - griežņa priekšējais leņķis, grādi;

$u_{z}$ - padeve uz griezni, $\mathrm{mm}$;

$\varphi_{\text {vid }}$ - vidējais leņķis starp griešanas un padeves kustības virzienu, grādi;

$\psi$ - konstante, kas atkarīga no griežņa ekspluatācijas ilguma funkcijas vērsuma attiecībā pret koordinātu sistēmas, kurā tā ir attēlota, asīm;

$f$ - koeficients, kas ir atkarīgs no griežņa priekšejjā leņķa;

$\kappa$ - koeficients, kas ir atkarīgs no padeves uz griezni;

$g$ - koeficients, kas ir atkarīgs no vidējā leņķa starp griešanas un padeves kustības virzienu;

$C$ - konstante, kura ir vienāda ar naturāllogaritmu no griežņa ekspluatācijas ilguma funkcijas krustpunkta vērtības ar koordinātu sistēmas, kurā tā ir attēlota, ordinātu asi.

Katrs no griežņa nodilumu ietekmējošajiem faktoriem $L$ izmaina par noteiktu vērtību attiecībā pret $L$, kāds kritiskā nodiluma perioda sākumā ir novērots 1. eksperimentā $\quad\left(v=50 \mathrm{~m} \mathrm{~s}^{-1}, \quad \gamma=15\right.$ grādi, $\quad u_{z}=0.503 \mathrm{~mm}$, 
$\varphi_{\text {vid }}=36.9$ grādi), jo katram griešanas režīma parametram viens no mainīgajiem atbilst šì eksperimenta režīmam. Tādēl koeficientu $f, \kappa$, un $g$ aprēḳināšanai var lietot formulas, ar kurām iespējams aprēḳināt, cik reizes $L$ izmainās attiecībā pret 1 . eksperimentā novēroto $L$ :

$$
\begin{gathered}
f_{i}=-\psi \cdot \log _{\gamma_{i}} \frac{L_{\rho \gamma_{i}}}{L_{\rho \gamma_{0}}}, \\
\kappa_{i}=-\psi \cdot \log _{u_{z i}} \frac{L_{\rho u_{z i}}}{L_{\rho u_{z 0}}}, \\
g_{i}=-\psi \cdot \log _{\varphi_{v i d} i} \frac{L_{\rho \varphi_{\text {vid }}}}{L_{\rho \varphi_{v i d} 0}},
\end{gathered}
$$

kur $\quad f_{i}-$ koeficients, kas ir atkarīgs no griežņa priekšējā leņķa;

$\kappa_{i}$ - koeficients, kas ir atkarīgs no padeves uz griezni;

$g_{i}$ - koeficients, kas ir atkarīgs no vidējā leṇkşa starp griešanas un padeves kustības virzienu;

$\psi$ - konstante, kas atkarīga no griežņa ekspluatācijas ilguma funkcijas vērsuma attiecībā pret koordinātu sistēmas, kurā tā ir attēlota, asīm;

$\gamma_{i}, u_{z i}, \varphi_{v i d i}$ - griežņa priekšējā leṇķa (padeves uz griezni, leņķa starp griešanas un padeves kustības virzienu) vērtības; grādi (mm, grādi);

$L_{\rho}$ - griešanas trajektorijas garums kritiskā griežņa nodiluma perioda sākumā atbilstoši $\gamma_{i}, u_{z i}, \varphi_{\text {vid } i}$ vērtībām, m;

$L_{\rho \gamma_{0}}, L_{\rho u_{z 0}}, L_{\rho \varphi_{v i d 0}}$ - griešanas trajektorijas garums kritiskā griežņa nodiluma perioda sākumā atbilstoši mainīgo griešanas režīma parametru vērtībām 1. eksperimentā, m.

Gan leņķa $\gamma$, gan $u_{z}$, gan arī leņķa $\varphi_{\text {vid }}$ ietekme uz griežņa nodilumu ir lineāra, kas nozīmē, ka piel̦aujams noteikt koeficientu $f, \kappa$, un $g$ vērtības tikai to minimālajai un maksimālajai robežai. Parametru robežvērtībām, kuras atbilst 1. eksperimenta datiem, koeficientus aprēķināt nav nepieciešams, jo var secināt, ka to vērtības ir vienādas ar 0 . Tādēl aprēķini jāveic tikai main̄̄go vērtību diapazonu beigu robežām, papildus ievērojot, ka koeficienta $\psi$ vērtība 
ir atšķirīga, mainoties $v$ diapazonam. Teilora formulas konstanšu un koeficientu aprēķinu kopsavilkums ir parādīts 2. tabulā.

2. tabula / Table 2

\section{Teilora formulas konstanšu un koeficientu vērtības / Values of constants and coefficients for Taylor's equation}

\begin{tabular}{|c|c|c|}
\hline $\begin{array}{c}\text { Griešanas ātrums } v, \mathrm{~m} \mathrm{~s}^{-1} / \\
\text { Cutting velocity } v, \mathrm{~m} \mathrm{~s}^{-1}\end{array}$ & 20 līdz / till 50 & 50 līdz / till 75 \\
\hline Konstante $C$ / Constant $C$ & $1.233 \cdot 10^{-11}$ & $5.465 \cdot 10^{19}$ \\
\hline Konstante $\psi /$ Constant $\psi$ & -3.060 & 4.378 \\
\hline $\begin{array}{c}\text { Griežņa priekšējais } \\
\text { leṇkis } \gamma \text {, grādi / } \\
\text { Rake angle } \gamma \text {, degree }\end{array}$ & \multicolumn{2}{|c|}{ Koeficients $f$ / Coefficient $f$} \\
\hline 15 līdz / till 20 & $0.0000 \mathrm{lī} \mathrm{dz} /$ till 0.1018 & $\begin{array}{l}0.0000 \mathrm{lī} \mathrm{dz} / \mathrm{till} \\
-0.1456\end{array}$ \\
\hline 20 līdz / till 25 & 0.1018 līdz / till 0.1581 & $\begin{array}{c}-0.1456 \text { līdz / till } \\
-0.2262\end{array}$ \\
\hline 25 līdz / till 30 & 0.1581 līdz / till 0.2127 & $\begin{array}{c}-0.2262 \mathrm{lī} \mathrm{dz} / \mathrm{till} \\
-0.3043\end{array}$ \\
\hline $\begin{array}{l}\text { Padeve uz griezni } u_{z}, \mathrm{~mm} / \\
\text { Feed per tooth } u_{z}, \mathrm{~mm}\end{array}$ & \multicolumn{2}{|c|}{ Koeficients $\kappa$ / Coefficient $\kappa$} \\
\hline $0.251 \mathrm{lī} \mathrm{dz} /$ till 0.503 & $\begin{array}{c}-0.0930 \text { līdz / till } \\
0.0000\end{array}$ & 0.1330 līdz / till 0.0000 \\
\hline $0.503 \mathrm{lī} \mathrm{dz} /$ till 0.754 & $0.0000 \mathrm{lī} \mathrm{dz} /$ till 1.2286 & $\begin{array}{l}0.0000 \mathrm{līdz} / \text { till } \\
-1.7577\end{array}$ \\
\hline 0.754 līdz / till 1.005 & $\begin{array}{c}1.2286 \text { līdz / till } \\
173.0200\end{array}$ & $\begin{array}{c}-1.7577 \text { līdz / till } \\
-247.5450 \\
\end{array}$ \\
\hline $\begin{array}{c}\text { Vidējais lenkkis starp } \\
\text { griešanas un padeves } \\
\text { kustības virzienu } \varphi_{\text {vid }} \text {, } \\
\text { grādi / Mean angle between } \\
\text { the direction of the cutting } \\
\text { and feed movement } \\
\varphi_{\text {vid }} \text {, degree }\end{array}$ & \multicolumn{2}{|c|}{ Koeficients $g$ / Coefficient $g$} \\
\hline 18.2 līdz / till 25.8 & 0.2650 līdz / till 0.1716 & $\begin{array}{c}0.3792 \mathrm{līdz} / \text { till } \\
-0.2455\end{array}$ \\
\hline 25.8 līdz / till 31.8 & 0.1716 līdz / till 0.0957 & $\begin{array}{c}-0.2455 \mathrm{lī} d \mathrm{~d} / \text { till } \\
-0.1369\end{array}$ \\
\hline 31.8 līdz / till 36.9 & 0.0957 līdz / till 0.0000 & $\begin{array}{c}-0.1369 \text { līdz / till } \\
0.0000\end{array}$ \\
\hline
\end{tabular}


Rezultātā griežņa kritiskā nodiluma sākumam atbilstošā griešanas trajektorijas garuma prognozēšanai atkarībā no griešanas ātruma, griežņa priekšējā leņķa, padeves uz griezni un leņķa starp griešanas un padeves kustības virzienu iespējams lietot 2. tabulā parādītās konstanšu un koeficientu vērtības un šādu formulu, kura iegūta no 4.6. formulas:

$$
L=C^{\frac{1}{\psi}} \cdot v^{\frac{-1}{\psi}} \cdot \gamma^{\frac{-f}{\psi}} \cdot u_{z}^{\frac{-\kappa}{\psi}} \cdot \varphi_{v i d}^{\frac{-g}{\psi}}
$$

Formula (4.10) norāda viena zāǵripas griežņa piel̦aujamo griešanas trajektorijas garumu, tādēl iegūtais rezultāts vēl ir jāsareizina ar faktisko zāğripas griežņu skaitu. Savukārt griešanas trajektorijas garumam kritiskā griežņa nodiluma perioda sākumā atbilstošo elektriskās jaudas vērtību iespējams noteikt, izmantojot 3.5. formulu, kas norāda vatmetra, kas pievienots griešanas mehānisma elektromotoram, rādījumu.

\section{SECINĀJUMI}

1. Griešanas procesā patērētā elektriskā jauda, īpatnējais griešanas darbs (spēks) un griežña nodilums (griezējšksautnes noapaļojuma rādiuss), ir būtiski atkarīgi no griešanas režīma faktoriālajiem parametriem - griešanas ātruma, griežņa priekšējā leņķ̧a, padeves uz griezni, vidējā leņķa starp griešanas un padeves kustības virzienu - un griešanas trajektorijas garuma, virsmas raupjums ir būtiski atkarīgs no griežṇa priekšējā leṇka un griešanas trajektorijas garuma (griežņa nodiluma), bet mehāniskā griešanas jauda ir būtiski atkarīga tikai no elektriskās jaudas, ja tās prognozēěanas modelī iekḷauj gan elektrisko jaudu, gan griešanas režīma faktoriālos parametrus.

2. Mehāniskā griešanas jauda, kas iegūta no griešanas spēka mērījumiem, un elektriskā jauda, kas iegūta no strāvas stipruma un sprieguma mērījumiem, nav vienādas. Elektriskā jauda, garenzāgẹ́jot apses koksni, ir 1.11 līdz 1.34 reizes lielāka par mehānisko griešanas jaudu.

3. İpatnējā griešanas darba (spēka) palielināšanos, palielinoties griešanas trajektorijas garumam, izraisa griežña nodilums, tādēl tā pieaugums ir līdzvērtīgs griežņa nolietojuma novērtēšanas koeficientam $a_{\rho}$, kura aprēḳināšana līdz ar to pamatojas ne tikai uz griežņa darba ilguma pēc asināšanas, bet arī uz griešanas trajektorijas garumu, griešanas ātrumu, griežņa priekšējo leņķi, padevi uz griezni un vidējo leņksi starp griešanas un padeves kustîbas virzienu.

4. Griešanas procesā patērētā elektriskā jauda samazinās par $32 \%$, ja griešanas ātrums palielinās no 20 līdz $59 \mathrm{~m} \mathrm{~s}^{-1}$, par 17 līdz $42 \%$, ja 
griežņa priekšējais leņkis palielinās no 15 līdz 30 grādiem, par $128 \%$, ja padeve uz griezni samazinās no 1.005 līdz $0.471 \mathrm{~mm}$, un par $96 \%$, ja vidējais leņkis starp griešanas un padeves kustības virzienu samazinās no 36.9 līdz 18.2 grādiem.

5. Viena zāğripas griežņa piestrādes nodiluma perioda ilgums, pamatojoties uz griezējšķautnes noapaļojuma rādiusa izmaiņām, ir līdz 1500 griešanas trajektorijas garuma metriem, kas nav būtiski atkarīgs no griešanas režīma faktoriālajiem parametriem.

6. Viena zāğripas griežņa kritiskā nodiluma perioda sākuma robeža atkarībā no griešanas režīma faktoriālajiem parametriem ir 9700 līdz $16900 \mathrm{~m}$. Kritiskā nodiluma perioda sākuma robeža palielinās par $35 \%$, ja griešanas ātrums palielinās no 20 līdz $50 \mathrm{~m} \mathrm{~s}^{-1}$, par $27 \%$, ja griežņa priekšējais leņķis palielinās no 15 līdz 30 grādiem, par $32 \%$, ja padeve uz griezni samazinās no 1.005 līdz $0.503 \mathrm{~mm}$, un par $28 \%$, ja vidējais leņķis starp griešanas un padeves kustības virzienu samazinās no 36.9 līdz 18.2 grādiem.

7. Apses koksnes garenzāgeěšanā, ja griešanas ātrums ir diapazonā no 20 līdz $50 \mathrm{~m} \mathrm{~s}^{-1}$, griežņa nodiluma prognozēšanas Teilora formulas konstante $\psi=-3.060$, bet konstante $C=1.233 \cdot 10^{-11}$, savukārt, ja griešanas ātrums ir diapazonā no $50 \quad$ lìdz $75 \mathrm{~m} \mathrm{~s}^{-1}$, konstante $\psi=4.378$, bet konstante $C=5.465 \cdot 10^{19}$.

8. Izstrādātā griežņa nodiluma un elektriskās jaudas prognozēšanas metode, ievērojot griešanas ātrumu, griežņa priekšējo leņ̧i, padevi uz griezni, vidējo leņ̧̧i starp griešanas un padeves kustības virzienu un griešanas trajektorijas garumu, uzrāda būtisku ticamības līmeni.

\section{PRIEKŠLIKUMI}

1. Apses koksnes garenzāǵēěanā, lai palielinātu griešanas trajektorijas garumu līdz kritiskā nodiluma sākumam, līdz 29 \% samazinātu griešanas procesā patērēto jaudu un tādējādi arī elektroenerğijas izmaksas, jālieto griešanas režīms ar šādiem parametriem: griešanas ātrums $59 \mathrm{~m} \mathrm{~s}^{-1}$, griežņa priekšējais leņ̧⿻is 30 grādi, padeve uz griezni $0.471 \mathrm{~mm}$, bet vidējam leņķim starp griešanas un padeves kustības virzienu jābūt iespējami mazākam, ko iespējams panākt, ja sazāgeejjamais materiāls pozicionēts iespējami tuvāk zāgripas perifērijai. Citi griešanas režīma parametri jānosaka, pamatojoties uz iepriekšminētajiem lielumiem.

2. Zāg̣ripas griežņu starpasināšanas perioda griešanas trajektorijas garuma noteikšanai jālieto izstrādātā Teilora formula, tās koeficienti un konstantes, bet griešanas trajektorijas garumam $L, \mathrm{~m}$, atbilstošās 
elektriskās jaudas $N_{e l}, \mathrm{~W}$, vērtības noteikšanai atkarībā no griešanas ātruma $v, \mathrm{~m} \mathrm{~s}^{-1}$, griežņa priekšējā leņķa $\gamma$, grādi, padeves uz griezni $u_{z}, \mathrm{~mm}$, un vidējā leņķa starp griešanas un padeves kustības virzienu $\varphi_{\text {vid }}$, grādi, - regresijas vienādojumu: $N_{e l}=1.072 \cdot 10^{-2} \cdot L-$ $-6.750 \cdot v-5.989 \cdot 10^{-2} \cdot v^{2}-4.284 \cdot \gamma-230.849 \cdot u_{z}+259.407 \cdot u_{z}^{2}+$ $+3.029 \cdot \varphi_{\text {vid }}-2.235$.

3. Starpasināšanas perioda ilguma kontrole jāveic ar ripzāğmašīnas griešanas mehānisma elektromotoram uzstādīta vatmetra mērījumu rezultātiem, kurus iespējams savienot ar elektronisko informācijas sistēmu, kas raida brīdinājumu par kritiskā griežņa nodiluma perioda sākumu tiklīdz ir sasniegta aprēḳinātā elektriskās jaudas vērtība. 


\section{INTRODUCTION}

\section{Topicality of subject of doctoral thesis}

Wood processing industry more and more begins to focus on processing wood of soft deciduous trees, manufacturing not only decoration boards, but also structural building elements and furniture. Sawing is the major mechanical wood processing techniques that are applied during the technological process of manufacturing any type of products from wood. Furthermore, from all the wood cutting processes that are based on sawing, the most popular is longitudinal cutting with a circular saws. Studies with aim to determine the right cutting regime for longitudinal sawing and other processes are mostly carried out by processing wood of coniferous or hard deciduous trees. It may be attributed to the fact that the wood of soft deciduous trees originally were considered inferior and not suitable for mechanical processing, and because of that an insufficient amount of studies have been carried out regarding this type of wood both in Latvia and abroad. Therefore, the current regularities of processing the soft deciduous wood are based on regularities that have been learned during the cutting processes of wood of coniferous and hard deciduous trees. This creates a necessity to develop optimal cutting regimes and methods for prediction of tip bluntness of circular saw prescribed exactly for the processes of cutting soft deciduous wood, as it is anticipated that the use of these species of wood will only be increasing.

Cellular wood material is one of the specific wood products manufactured in Latvia in respect of which no rip sawing processes have been studied yet and which might be produced from wood of soft deciduous trees. Wood of coniferous trees is traditionally used for the production of cellular wood material and recovery period of wood of coniferous trees is greater compared to wood of soft deciduous trees. Besides producers of cellular wood material have to compete with producers of other products about availability of the wood of coniferous trees resources. Out of all species of soft deciduous trees, wood of aspen has the largest potential to become a raw material for production of cellular wood material, taking into account the available resources and regeneration abilities of the species.

\section{Aim of doctoral thesis}

To clarify factors of the cutting regime that influencing bluntness of the ripsaw blade carbide tip, regularities among tip bluntness and these factors and to create method for prediction of tip bluntness in longitudinal sawing of aspen wood. 


\section{Tasks of doctoral thesis:}

1. to analyze information of wood cutting processes, bluntness of the tip and its characterizing indicators;

2. to explore changes of resultative indicators of longitudinal sawing related to the cutting regime parameters;

3. to determine regularities of impact of analyzed and explored cutting regime parameters to the bluntness of the tip;

4. to create method for prediction bluntness of the tip depending on the cutting regime parameters that affecting tool bluntness.

\section{Materials and methods used in doctoral thesis}

A multifunctional computer numerical control machine Biesse Rover 325 and specially constructed circular saws with only two teeth has been used for cutting of wood specimens. Electronic measuring instruments have been used in determination of the results: data logger PicoLogADC-20, force sensors Measurement specialities FC2211, current data logger PicoLog CM3 and sensors Pico TA138, surface roughness measurement device Mahr Perthometer M2.

During the experiments, kerfs of aspen wood specimens were made according to the technologies used in processing of workpieces of cellular wood material. The impact of the cutting regime parameters on sawblade tip bluntness, cutting power, cutting force, surface roughness of wood has been determined by changing individual cutting regime parameters - cutting velocity (frequency of rotational), feed speed (feed per tooth), rake angle (clearance angle) and kerf height (angle between the direction of the cutting and feed movement).

MS Excel was used for mathematical processing and graphical representation of data acquired during the research while AutoCAD, SolidWorks, CorelDRAW and Adobe Photoshop was used for creation of figures.

\section{Hypothesis of doctoral thesis}

Cutting regime parameters - cutting velocity (frequency of rotational), feed speed (feed per tooth), rake angle (clearance angle) and kerf height (angle between the direction of the cutting and feed movement) - has significance affect on the resultative indicators of cutting process - bluntness of tip, cutting power, cutting force, surface roughness of treated wood. 


\section{Abstracts to be defendable in doctoral thesis:}

1. disposition of changes of separate resultative indicators of cutting process related to the length of cutting trajectory is equal to each other;

2. bluntness of the ripsaw blade carbide tip can be predicted by identifying regularities of other resultative indicators and its affecting factors;

3. permissible length of the cutting trajectory is substantially increasing by use of cutting regime with optimal values of its parameters.

\section{Scientific novelty of doctoral thesis}

1. New data of effect of cutting regime parameters on the cutting process and its performance indicators are obtained.

2. Regularities amid parameters of cutting regime and tip bluntness, cutting power, cutting force, surface roughness of treated wood are determined.

3. Designed, developed and approved research methodology of wood cutting processes.

4. Prediction method of tip bluntness, constants and coefficients based on Taylor's equation are designed for the first time in Latvia.

\section{Practical significance of doctoral thesis}

1. The developed cutting regime regularities may be used in rip sawing processes of production workpieces for cellular wood material and other materials.

2. Based on the developed regularities from Taylor's equation for tool bluntness, it is possible to predict the beginning boundary of the critical bluntness period of a ripsaw tip (period between sharpening).

3. The acquired data of the effects of cutting regime parameters on the cutting processes and the indicators characterising these parameters are published in international publications. Thus, they are available for other authors carrying out studies as well as preparing educational books.

\section{Structure of doctoral thesis}

Doctoral thesis is structured in seven sections:

1. „Analyze of wood cutting processes;

2. "Materials and methods";

3. „Results and its analyze";

4. „Prediction of bluntness of the carbide tip”;

5. "Costs of consumed power";

6. „Conclusions”;

7. „Suggestions”.

The doctoral thesis is designed on the 131 pages and includes 48 figures, 6 tables, 89 equations and 112 sources of references. 


\section{ANALYZE OF WOOD CUTTING PROCESSES}

The effects of cutting regime parameters on the cutting processes and their resultative indicators ascertained in earlier researches, by mainly focusing on bluntness of cutting tool, cutting power, cutting force, and roughness of the surface, are analysed in this section. In addition the prediction feasibility of bluntness of cutting tool as well as experience in respect to improvements of bluntness resistance is discussed. The following main conclusions have been performed after the analysis:

1. the resultative indicators of cutting process - bluntness of cutting tool, cutting power and force, roughness of wood surface - are mainly affected by four cutting regime parameters - cutting velocity, rake angle of the cutter, feed speed and kerf height. Therefore, the research should be continued by analysing only these four parameters;

2. investigations that describe duration of cutting tool bluntness periods rarely have been carried out in respect to cutting tools for longitudinal milling, while there is absolutely no information on duration of cutting tool bluntness periods for cutting tools used in rip sawing processes. It means that researche should be organised in a way that it would be possible to determine the length of individual bluntness periods of the cutting tool;

3. Taylor's equation is suitable for predicting bluntness of cutting tool, however, it is developed for metal cutting processes, meaning that there is no information on its constant and coefficient values in respect to the bluntness of cutting tools for wood processing. Besides the Taylor's equations is taking into account only the effects of cutting velocity, while it has been proven that cutting process is also affected by other indicators - mostly the angular parameters of the cutter, feed speed, chip thickness, and kerf height. In order to use the Taylor's equation for predicting the bluntness of cutting tools used in rip sawing of wood, it is necessary to identify the respective constants and coefficients of these other factors;

4. values of the coefficient describing bluntness of the cutting tool used in determining the specific cutting work (force) that is a significant parameter in calculating cutting power do not take into account all of the most significant factors affecting bluntness of the cutting tool, therefore, the research should provide solution for adjustment of the calculation method of this coefficient;

5. by using cryogenic treatment of cutters, it is possible to significantly increase their bluntness resistance (up to four times comparing to cutters that have not undergone cryogenic treatment), however, taking into account the labour input, time required for this treatment and that properties acquired during cryogenic tretment are lost after tip 
resharpening, it may not compete with other methods for increasing wear resistance - surface coating and helical cutting edge configuration.

\section{MATERIALS AND METHODS}

The research was carried out based on individually developed methodology.

1. Aspen (Populus tremula L.) wood samples with a depth of $28 \mathrm{~mm}$, width of $98 \mathrm{~mm}$ and length of $450 \mathrm{~mm}$ were used in the research. The cross-section of wood samples confirms to the dimensions of the workpieces used in production of cellular wood material.

2. Experiments were carried out with specially constructed circular saws (Table 1).

3. Duration of the research 13 separate experiments were done, in each of them changing the value of one of the main cutting regime parameters: cutting velocity $\left(20,35,50,75 \mathrm{~m} \mathrm{~s}^{-1}\right)$, rake angle of cutter (Table 1), feed speed $\left(4,8,12,16 \mathrm{~m} \mathrm{~min}^{-1}\right.$, equivalent to feed per tooth 0.251 till $1.257 \mathrm{~mm})$, kerf height $(6,12,18,24 \mathrm{~mm}$, equivalent to mean angle between the direction of the cutting and feed movement 18.2 till 36.9 degrees). The rest of the cutting regime parameters were determined based on these four main parameters.

4. Climb-sawing was carried out by creating longitudinal kerfs next to each other on the both wider sides of the wood sample, leaving $3 \mathrm{~mm}$ wide partition between the kerfs in accordance with the cutting technology used for workpieces of cellular wood material.

5. During the sawing processes, samples of wood were fastened in a special device that was intended for determining cutting force (to determine the mechanical cutting power arising out of it). This device consists of two platforms (one of them is moving in horizontally, while both of them together are moving vertically). There are five force sensors Measurement Specialities FC22 placed underneath these platforms. Data logger PicoLog ADC-20 and software PicoLog Recorder is used for storing and processing data gathered from force sensors.

6. Phase voltage and line amperage measurements were made in order to determine electric power consumed by the electric motor of the cutting mechanism. Voltage was measured by an analogue and digital voltmeter, while amperage with sensors Pico TA138, current data logger PicoLog CM3 and software PicoLog Recorder as well as digital direct connection ammeter Schneider Electric iAMP. 
7. Replication method was used to measure the radius of cutting edge, by pressing the cutting edge into a lead plate and analysing the imprints in a digital light microscope Keyence VHX - 100K.

8. Mahr Perthometer M2 device was used to measure the surface roughness of the treated wood samples (lateral surface of the kerfs).

9. The acquired data was mostly related to the length of the cutting trajectory for a single saw tip calculated with the following equations:

$$
\begin{gathered}
L_{k}=\frac{l \cdot n \cdot l_{p}}{10^{6} \cdot u \cdot z} \cdot m_{i} \cdot m_{p}, \\
l=\frac{10^{3} \cdot u}{n \cdot z}+\frac{\pi \cdot D}{360} \arccos \left(1-\frac{2 \cdot H}{D}\right),
\end{gathered}
$$

where $L_{k}-$ total length of cutting trajectory related to one tip, m;

$l$ - length of the cutting trajectory at one rotation of the circular saw, mm;

$n$ - rotation frequency of circular saw, $\min ^{-1}$;

$l_{p}$ - length of the wood sample, $\mathrm{mm}$;

$u$ - feed speed, $\mathrm{m} \mathrm{min}^{-1}$;

$z$ - number of tips of the circular saw;

$m_{i}$ - number of kerfs in the one wood sample $\left(m_{i}=10\right)$;

$m_{p}$ - number of wood samples;

$\pi$ - constant charactering ratio of circle circumference to its diameter $(\pi=3.14)$;

$D$ - diameter of cutting circumference, $\mathrm{mm}$;

$H$ - kerf height, $\mathrm{mm}$.

10. The effects of the cutting regime parameters on the resultative indicators of cutting process was analysed by applying correlation, regression and covariance methods. Statistical hypothesis has been tested with significance level $\alpha=0.05$. 


\section{RESULTS AND ITS ANALYZE}

\subsection{Analyze of cutting power}

By analysing changes in electric power $\left(N_{e l}\right)$ and mechanical cutting power $\left(N_{g r}\right)$ based on the main parameters of the cutting regime, it was ascertained that the consumed power was evenly increasing throughout the whole length of the cutting trajectory $(L)$. At the beginning of the experiment, $N_{e l}$ was 1.11 larger than $N_{g r}$, while at the end of the experiment this proportion was 1.34 . Thus, by measuring $N_{e l}$, it is not possible to obtain the actual cutting power that is directly arising from the cutting force. The electric power consumed by the motor is an indirect characteristic that is rather easily definable. Results of the research show that the main parameters of the cutting regime significantly affect power consumption and these measurements may be used to control the bluntness level of the ripsaw tip.

The second degree polynomial function provides the best explanation ( $99.3 \%$ ) of the changes in $N_{e l}$ based on the cutting velocity ( $v$ ):

$$
N_{\text {elv }}=1.459 \cdot 10^{-2} \cdot L-10.962 \cdot v+9.239 \cdot 10^{-2} \cdot v^{2}+382.541,
$$

where $N_{e l v}$ - electric power depending on cutting velocity values ranging from 20 to $75 \mathrm{~m} \mathrm{~s}^{-1}, \mathrm{~W}$;

$L$ - length of cutting trajectory related to one tip, m; $v$ - cutting velocity, $\mathrm{m} \mathrm{s}^{-1}$.

Hypersurface (Figure 3.1) with a probability of $P=99.9 \%$ shows that $N_{e l}$ will increase by $1.459 \cdot 10^{-2}$ units if $L$ is increased by one meter. In its turn, if $v$ increases by one unit within the range from 20 to $59 \mathrm{~m} \mathrm{~s}^{-1}, N_{e l}$ will decrease by the sum of decrease in value of power caused by the previous single unit and $1.848 \cdot 10^{-1}$. Whereas if $v$ increases by one unit within the range from 59 to $75 \mathrm{~m} \mathrm{~s}^{-1}, N_{e l}$ will increase by the sum of increase in value of power caused by the previous single unit and $1.848 \cdot 10^{-1}$. The results show that the most optimal $v$ causing providing the lowest power consumption is $59 \mathrm{~m} \mathrm{~s}^{-1}$.

Regression analysis confirms that $L$ and the rake angle of the cutter $(\gamma)$ significantly affects $N_{e l}$ (Figure 3.2) and that is described in the following equation:

$$
N_{e l \gamma}=8.942 \cdot 10^{-3} \cdot L-4.058 \cdot \gamma+170.712
$$

where $N_{e l \gamma}-$ electric power depending on rake angle of the tip values ranging from 15 to 30 degrees, $\mathrm{W}$; 
$L$ - length of cutting trajectory related to one tip, m;

$\gamma$ - rake angle of the tip, degree.

The hyper-plane (Figure 3.2) of the regression indicates that $N_{e l}$ increases due to $L$ is increasing that is explainable by gradual rounding of the cutting edge progressively affecting the thickness of the wood layer that must be deformed by the tip underneath centre of the rounding radius (deformation of a thicker layer of wood requires more work and thus more power). Conversely the angle $\gamma$ effect on $N_{e l}$ is expressed in a way that $N_{e l}$ increases if the values of angle $\gamma$ decrease. Such effect is explained by the fact that, by decreasing the angle $\gamma$, the front surface of the tip tends to assume a parallel position with the radius vector of the cutting circumference and the degree of crook of chip elements increase in the chip formation area above the radius centre of the roundness of the cutting edge. In order to obtain a degree of crook that has a tendency moving towards a narrower angle, increased work input and power is required. Besides, an increasing directivity of the cutter's front plane decreases the possibility of formation of micro-cracking on the wood in front of the cutting edge that would also decrease resistance of the wood. It means that in rip sawing processes it is efficient to choose cutting tools with a higher angle $\gamma$ value as that will decrease power consumption. By increasing the angle $\gamma$ from 15 to 20 degrees, $N_{e l}$ will decrease by $17 \%$, from 20 to 25 degrees by $21 \%$, and from 25 to 30 degrees - by $25 \%$. Conversely, if the angle $\gamma$ is increased from 15 to 30 degrees, the electric power consumption decreases by up to $42 \%$. However, such decrease in power consumption is observed only at the beginning of the cutting process - during the first 1000 meters of $L-$ because effect of the initial bluntness of the tip is appeared in there. It has been ascertained that by increasing $L$, the decrease in power consumption is gradually becoming lower until at the end of the cutting process (after reaching $19000 \mathrm{~m}$ of $L$ ) the aforementioned percentages of decrease in power consumption are $7.25 \%, 7.82 \%, 8.49 \%$ and $17.8 \%$ respectively. Such gradual decrease in the impact of the angle $\gamma$ on $N_{e l}$ based on $L$ indicates that the angular values of the tip have been changed in direct proximity of the cutting edge during the final phase of the cutting process caused by wear of the tip during the critical bluntness period. Thus, further use of the cutting tool after reaching the critical bluntness period is undesirable not only because of the decrease in the overall tip life, but also because of the decrease in the angle $\gamma$ that has been measured in direct proximity of the cutting edge in respect to the tangents of the rounded part of the cutting edge.

Feed speed in the rip sawing process affects the feed per tooth $\left(u_{z}\right)$, thickness of chip, $L$ as well as the load working on the tip and accumulation capacity of chip within the gaps of the teeth. Besides, $u_{z}$ has a direct effect on 
the cutting force and power because as different combinations of feed speed and circular saw rotation frequency may have variable feed speed but the same $u_{z}$ and thus the load working on the tip may be constant under different feed speeds. Feed speed is one of the basic parameters of a cutting regime, but it is not advantageous for compare several cutting regimes. Parameter $u_{z}$ is the indicator that is appropriate to compare different cutting regimes. Changes of $N_{e l}$ based on $L$ and $u_{z}$ are described by the following multifactor regression model:

$$
N_{e l u_{z}}=1.353 \cdot 10^{-2} \cdot L-454.720 \cdot u_{z}+484.542 \cdot u_{z}^{2}+181.514
$$

where $N_{e l u_{z}}$ - electric power depending on feed per tooth values ranging from 0.251 to $1.257 \mathrm{~mm}, \mathrm{~W}$;

$L$ - length of cutting trajectory related to one tip, m;

$u_{z}-$ feed per tooth, $\mathrm{mm}$.

Changes of $N_{e l}$ based on $u_{z}$ do not show any unequivocal affection (Figure 3.3). If $u_{z}$ is increased by $0.001 \mathrm{~mm}$ within the range from 0.251 to $0.471 \mathrm{~mm}, N_{e l}$ decreases by the sum of decrease in $N_{e l}$ caused by the previous $u_{z}$ unit and $9.691 \cdot 10^{-3}$. However, when $u_{z}$ changes within the range from 0.471 to $1.257 \mathrm{~mm}$, it is possible observe a completely opposite reaction $-N_{e l}$ increases by the sum of increase in $N_{e l}$ caused by the previous unit of $u_{z}(0.001 \mathrm{~mm})$ and $9.691 \cdot 10^{-3}$. It means that the optimal $u_{z}$ value that causes the lowest power consumption is $0.471 \mathrm{~mm}$. This $u_{z}$ value conforms to the feed speed of $7.5 \mathrm{~m} \mathrm{~min}^{-1}$ in range of the research.

The effect of kerf height on the cutting process was determined by using the mean angle between the direction of the cutting and feed movement $\left(\varphi_{\text {vid }}\right)$ as it is the best way to describe the relation between the cutter and wood fibres. Even though the kerf height is positioned as one of the main cutting regime parameters, it should be regarded as an acquisition parameter for angle $\varphi_{v i d}$. Coherence between $N_{e l}, L$ and angle $\varphi_{v i d}$ is described by the following linear multifactor regression model:

$$
N_{e l \varphi_{v i d}}=8.687 \cdot 10^{-3} \cdot L+2.971 \cdot \varphi_{v i d}+4.04 \cdot 10^{-1},
$$

where $\quad N_{e l} \varphi_{v i d}$ - electric power depending on mean angle between the direction of the cutting and feed movement values ranging from 18.2 to 36.9 degrees, $\mathrm{W}$;

$L$ - length of cutting trajectory related to one tip, m; 
$\varphi_{\text {vid }}$ - mean angle between the direction of the cutting and feed movement, degree.

Previously described equations explain the changes of $N_{e l}$ based on one of the main or derived cutting regime parameters $-v$, angle $\gamma, u_{z}$ and angle $\varphi_{\text {vid }}$. By analysing these equations it has been ascertained that there is a significant effect on $N_{e l}$. Therefore it is possible propose a hypothesis that there are significant simultaneous effects of all four cutting regime parameters on changes of $N_{e l}$ based on $L$. By obtaining such coherence, it is possible to calculate the value of $N_{e l}$ that conforms to the beginning of the period when sharpening of the tips of circular saw must be done. The proposed hypothesis is proved by the following regression model that explains $80.5 \%$ of the changes in $N_{e l}$ :

$$
\begin{aligned}
N_{e l}= & 1.072 \cdot 10^{-2} \cdot L-6.750 \cdot v-5.989 \cdot 10^{-2} \cdot v^{2}-4.284 \cdot \gamma- \\
& -230.849 \cdot u_{z}+259.407 \cdot u_{z}^{2}+3.029 \cdot \varphi_{v i d}-2.235,
\end{aligned}
$$

where $N_{e l}$ - electric power depending on cutting velocity values ranging from 20 to $75 \mathrm{~m} \mathrm{~s}^{-1}$, rake angle of tip values ranging from 15 to 30 degrees, feed per tooth values ranging from 0.251 to $1.257 \mathrm{~mm}$ and mean angle between the direction of the cutting and feed movement values ranging from 18.2 to 36.9 degrees, W; $L$ - length of cutting trajectory related to one tip, m;

$v$ - cutting velocity, $\mathrm{m} \mathrm{s}^{-1}$;

$\gamma$ - rake angle of tip, degree;

$u_{z}$ - feed per tooth, mm;

$\varphi_{v i d}-$ mean angle between the direction of the cutting and feed movement, degree.

Regression analysis shows the neither the main cutting regime parameters nor the interaction between these parameters not significantly effect to $N_{g r}$ based on $N_{e l}$. Therefore the relationship between $N_{g r}$ and $N_{e l}$ is linked by the following linear regression equation that explains $86.7 \%$ of the changes in the resultative indicator:

$$
N_{g r}=7.915 \cdot 10^{-1} \cdot N_{e l}-1.571
$$

where $\quad N_{g r}-$ mechanical cutting power, W;

$$
N_{e l} \text { - electrical power, W. }
$$




\subsection{Analyze of specific cutting work (force)}

The important indicator for calculating cutting power is the specific cutting work or specific cutting force $(K)$ that describes work that is required in order to cut off chip with a volume of one $\mathrm{cm}^{3}$. The other expression of this indicator is associated with determination of the specific cutting force that characterizes the force required to cut off the chip with a cross-section of one $\mathrm{mm}^{2}$. Taking into account that one $\mathrm{J} \mathrm{cm}^{-3}$ is equal to one $\mathrm{N} \mathrm{mm}^{-2}$, both indicators is expressed with one and the same parameter. Consequently determining of the specific cutting work $(K)$ will determine the specific cutting force at the same time, therefore only one of these indicators can be included in analyze. The following multifactor regression models describe changes in $K$ based on $L$ and factorial parameters of the cutting regime:

$$
\begin{gathered}
K_{v}=1.448 \cdot 10^{-3} \cdot L-9.358 \cdot 10^{-1} \cdot v+7.857 \cdot 10^{-3} \cdot v^{2}+30.806, \\
K_{\gamma}=8.907 \cdot 10^{-4} \cdot L-2.897 \cdot 10^{-1} \cdot \gamma+12.202, \\
K_{u_{z}}=1.199 \cdot 10^{-2} \cdot L-6.825 \cdot u_{z}+2.791 \cdot 10^{-1} \cdot u_{z}^{2}+43.497, \\
K_{\varphi_{v i d}}=1.898 \cdot 10^{-3} \cdot L-1.489 \cdot \varphi_{v i d}+451.696,
\end{gathered}
$$

where $K_{v}-$ specific cutting work accordingly values of cutting velocity ranging from 20 to $75 \mathrm{~m} \mathrm{~s}^{-1}, \mathrm{~J} \mathrm{~cm}^{-3}$;

$K_{\gamma}$ - specific cutting work accordingly values of rake angle of tip ranging from 15 to 30 degrees, $\mathrm{J} \mathrm{cm}^{-3}$;

$K_{u_{z}}$ - specific cutting work accordingly values of feed per tooth ranging from 0.251 to $1.005 \mathrm{~mm}, \mathrm{~J} \mathrm{~cm}^{-3}$;

$K_{\varphi_{v i d}}$ - specific cutting work accordingly values of mean angle between the direction of the cutting and feed movement ranging from 18.2 to 36.9 degrees, $\mathrm{J} \mathrm{cm}^{-3}$;

$L$ - length of cutting trajectory related to one tip, m;

$v$ - cutting velocity, $\mathrm{m} \mathrm{s}^{-1}$.

$\gamma$ - rake angle of tip, degree.

$u_{z}-$ feed per tooth, mm.

$\varphi_{\text {vid }}$ - mean angle between the direction of the cutting and feed movement, degree. 
The following main conclusions have been performed in $K$ analysis:

1 . by comparing the cutting power values obtained during the measurements with the calculated values, it may be concluded that the measured power is larger than the calculated power; it points out deficiencies in calculation formulas as the formula for determining $K$ is scantily taking into account not only the mechanical properties and density of wood, but also bluntness of the tip;

2. the bluntness of the tip is described by a coefficient $a_{\rho}$ based on working time of the tip after sharpening in calculation of the specific cutting force, while the working time of the tip is a very relative indicator as it depends on the feed speed - different $L$ and thus different bluntness of the tip may be achieved in the same time period if the feed speed is different;

3. $K$ value is constant under specific cutting regime circumstances, therefore its increase based on $L$ is caused by bluntness of the tip. It means that the product of direction coefficient and $L$ may be equated to the coefficient $a_{\rho}$ increase in the regression equation;

4. $K$ increases if $v$ decreases from 50 to $20 \mathrm{~m} \mathrm{~s}^{-1}$ and increases from 50 to $75 \mathrm{~m} \mathrm{~s}^{-1}$. The increase based on $L$ is related to increase in bluntness of the tip, while based on $v$ - to decrease in the dynamic stability of the ripsaw blade;

5. $K$ increases linearly throughout the whole range of angle $\gamma$ that was tested - from 15 to 30 degrees;

6. $u_{z}$ affects $K$ parabolically $-K$ increases when $u_{z}$ decreases which is completely opposite from how $u_{z}$ affects $N_{e l}$. The lowest $K$ value conforms to $u_{z}$ from 0.471 to $0.771 \mathrm{~mm}$;

7. $K$ gradually increases if $L$ is increasing and angle $\varphi_{\text {vid }}$ is decreasing. Thus, the effects of the kerf height on $K$ by decreasing chip thickness is larger than the effects of the cutting direction in respect to the orientation of wood fibres.

\subsection{Analyze of surface roughness}

The impact of angle $\gamma$ only analysed in the section on use of the surface roughness $\left(R_{z}\right)$ to predict bluntness of the tip as the rest of the main cutting regime parameters did not show any significant impact on surface roughness in relation to bluntness of the tip that may be explained by anisotropy of wood.

The following conclusions have been performed in analysis of $R_{z}$ :

1 . by increasing angle $\gamma$ from 15 to 30 degrees, the actual values of $R_{z}$ increases insignificantly, while the intensity of its growth decreases; 
2. during the initial bluntness period of the tip, $R_{z}$ increases at an intensity from $5.326 \cdot 10^{-3}$ to $5.888 \cdot 10^{-3} \mu \mathrm{m} \mathrm{m}^{-1}$ that is not significantly dependent on the angle $\gamma$;

3. during the monotone bluntness period of the tip, $R_{z}$ increases at an intensity from $5.189 \cdot 10^{-4}$ to $1.593 \cdot 10^{-3} \mu \mathrm{m} \mathrm{m}^{-1}$ that is 3.6 to 11.6 times lower comparing to the initial bluntness period;

4. during the critical bluntness period of the tip, $R_{z}$ increase at an intensity from $1.061 \cdot 10^{-2}$ to $2.175 \cdot 10^{-2} \mu \mathrm{m} \mathrm{m}^{-1}$ that is 9.2 to 41.9 times higher comparing to the monotone bluntness period and 2.0 to 3.7 times higher comparing to the initial bluntness period;

5. the values of coefficient of determination for curves and straight lines of $R_{z}$ are relatively low that is related to anisotropy of wood. It means that the bluntness of the tip not always may be explained by changes in exactly $R_{z}$. Thus, it may be concluded that even though the $R_{z}$ equations are statistically significant they should have only informative meaning, while the changes of the roundness radius of the cutting edge must be used for prediction of bluntness of the tip.

\subsection{Analyze of roundness of the cutting edge}

By analysing changes in roundness radius $\rho$ of the cutting edge based on the cutting velocity $\left(20 \mathrm{~m} \mathrm{~s}^{-1}\right)$, it has been ascertained that the initial bluntness period lies within the boundaries of $L$ from 0 to $900 \mathrm{~m}$ (Figure 3.5) that corresponds to a cutting time of approximately 10 minutes. Radius $\rho$ during this period increases at an intensity of $9.163 \cdot 10^{-3} \mu \mathrm{m} \mathrm{m}^{-1}$. After that, the intensity of the increase in radius $\rho$ decreases. It indicates beginning of the monotone bluntness period of the tip that continues until reaching approximately $9700 \mathrm{~m}$ in cutting trajectory length with the respective cutting time of 106 minutes. During this period, radius $\rho$ increases at an intensity of $3.314 \cdot 10^{-3} \mu \mathrm{m} \mathrm{m}^{-1}$ - increase in rounding intensity of the cutting edge is 2.76 lower comparing to the initial bluntness period. After the end of the monotone bluntness period, radius $\rho$ is rapidly increasing again indicating the beginning of the critical bluntness period. During the critical bluntness period, radius $\rho$ increases at an intensity of $9.685 \cdot 10^{-3} \mu \mathrm{m} \mathrm{m}^{-1}-$ the intensity of the rounding increase is 2.92 times higher comparing to the monotone bluntness period and 1.05 times higher comparing to the initial bluntness period.

In their turn if the cutting velocity is $50 \mathrm{~m} \mathrm{~s}^{-1}$, the initial bluntness period lies within the boundaries of $L$ from 0 to approximately $1000 \mathrm{~m}$, but the cutting time is around 4.5 minutes. During this period, radius $\rho$ increases at an 
intensity of $7.623 \cdot 10^{-3} \mu \mathrm{m} \mathrm{m}^{-1}$. The monotone bluntness period of the tip starts right after and continues until reaching approximately $13100 \mathrm{~m}$ in cutting trajectory length with the respective cutting time of 58.5 minutes. During this period, radius $\rho$ increases at an intensity of $2.298 \cdot 10^{-3} \mu \mathrm{m} \mathrm{m}^{-1}-$ increase in rounding intensity of the cutting edge is 3.3 times lower comparing to the initial bluntness period. The critical wear period starts after the length of the cutting trajectory reaches approximately $13100 \mathrm{~m}$ where the radius $\rho$ increases at an intensity of $7.817 \cdot 10^{-3} \mu \mathrm{m} \mathrm{m}^{-1}$ - the intensity of the rounding increase of the cutter is 3.4 times higher comparing to the monotone bluntness period and 1.03 times higher comparing to the initial bluntness period.

At the beginning of the cutting process, radius $\rho$ is from 4 to $5 \mu \mathrm{m}$, while at the end of the initial bluntness period it increases almost three times -13 to $14 \mu \mathrm{m}$. However, at the beginning of the critical bluntness period of the tip, the radius $\rho$ increases till 41 to $43 \mu \mathrm{m}$ (Figure 3.6). By comparing the increase in radius $\rho$, it may be concluded that the length of the cutting trajectory is different after the critical bluntness period has started - the critical bluntness period starts $33.6 \%$ later if the cutting velocity is increased from 20 to $50 \mathrm{~m} \mathrm{~s}^{-1}$. The same coherence may be seen in the comparison between the cutting velocities of $20 \ldots 35 \mathrm{~m} \mathrm{~s}^{-1}$ and $35 \ldots 50 \mathrm{~m} \mathrm{~s}^{-1}$, while cutting trajectory decreases when comparing the cutting velocity of 50 and $75 \mathrm{~m} \mathrm{~s}^{-1}$ (Figure 3.7). Regression analysis equation with a probability of $P=99.9 \%$ describes the significant impact of the cutting velocity on bluntness of the tip (Figure 3.7).

It has been ascertained that the rake angle of the cutter linearly impacts the beginning of the critical bluntness period. By increasing the angle $\gamma$ from 15 to 20 degrees, the critical bluntness period starts by $10 \%$ later comparing to if the angle $\gamma$ is left at 15 degrees and by $7 \%$ later if the angle $\gamma$ is increased from 20 to 25 or 25 to 30 degrees respectively. It proves the fact the most optimal angle $\gamma$ is 30 degrees as it not only decreases the power consumption but also increases the period between sharpening. Regression analysis equation with a probability of $P=99.7 \%$ describes the significant impact of the angle $\gamma$ (Figure 3.8).

According to the regression, the feed per tooth, which is an indicator describing the character of the feed movement, impacts the beginning of the critical bluntness period linearly. These indicators have a strong negative correlation $(r=0.976)$ that means that by increasing the $u_{z}$ values the critical bluntness period begins earlier as the load working on the tip increases as well - the tip needs to cut off larger volume of wood within the same time period. By increasing $u_{z}$ from 0.251 to $0.503 \mathrm{~mm}$, the critical bluntness period starts by $4.5 \%$ earlier comparing to feed per tooth $0.251 \mathrm{~mm}$, by $10 \%$ earlier in respect to $u_{z}=0.503 \mathrm{~mm}$ if the feed per tooth is increased 
from 0.503 to $0.754 \mathrm{~mm}$, and by $14 \%$ earlier in respect to $u_{z}=0.754 \mathrm{~mm}$ if $u_{z}$ is increased from 0.754 to $1.005 \mathrm{~mm}$. The significance of the impact made by feed per tooth with a probability of $P=97.6 \%$ is proven by a linear regression analysis equation (Figure 3.9).

Correlation analysis in respect to the impact of the mean angle between the direction of the cutting and feed movement on the length of the cutting trajectory at the beginning of the critical bluntness period show a tight negative correlation $(r=0.987)$. The critical bluntness period starts earlier by increasing value of the angle $\varphi_{v i d}$. This is similar to the impact caused by $u_{z}$ as increase in both of these indicators also increase thickness of chip and thus volume of chip cut off within a unit of time increasing the power consumption and facilitating bluntness of the tip. By increasing angle $\varphi_{\text {vid }}$ from 18.2 to 25.8 degrees, $L$ decreases by $6.5 \%$ until the beginning of the critical bluntness period; by increasing angle $\varphi_{\text {vid }}$ from 25.8 to 31.8 degrees, $L$ decreases by $7.1 \%$; and by increasing angle $\varphi_{\text {vid }}$ from 31.8 to 36.9 degrees, $L$ decreases by $10.2 \%$. The significance of the impact made by angle $\varphi_{\text {vid }}$ with a probability of $P=98.7 \%$ is proven by a linear regression analysis equation (Figure 3.10).

Based on the obtained regularities between the main cutting regime parameters and length of cutting trajectory which is the beginning of the critical bluntness period, it may be concluded that the results may be used in predicting bluntness of the tip by applying the Taylor's equation.

\section{PREDICTION OF CARBIDE TIP BLUNTNESS}

Taylor's equation is useful for prediction of bluntness of the tip as it is determined in analyze of wood cutting processes. However there is necessary to establish modifications of Taylor's equation due to length of the cutting trajectory is more appropriate for prediction of tip bluntness compared to time of cutting because the time depends on the feed speed:

$$
v \cdot L^{\psi}=C,
$$

or

$$
\ln v+\psi \cdot \ln L=\ln C,
$$

where $\quad v$ - cutting velocity, $\mathrm{m} \mathrm{s}^{-1}$;

$L$ - length of cutting trajectory related to one tip, m;

$\psi-$ a constant which depends on slope of the curve which depends on tool bluntness; 
$C$ - a constant which is equal to the naturallogarithm of intercept of the curve of the tool bluntness and the ordinate.

Whereas, constant $\psi$ can be characterized by this equation inasmuch as changes of the tip bluntness are inverse to the classical Taylor's equation (Figure 3.7) in range of cutting velocity inspected in the research:

$$
\psi_{i}=-1 \cdot \frac{\ln v_{1}-\ln v_{2}}{\ln L_{1}-\ln L_{2}},
$$

where $\psi_{i}-$ a constant which depends on slope of the curve which depends on tool bluntness dependent on range of cutting velocity; $v_{1} ; v_{2}$ - different values of cutting velocity, $\mathrm{m} \mathrm{s}^{-1}$;

$L_{1} ; L_{2}$ - lengths of cutting trajectory related to one tip corresponding to cutting velocities $v_{1}$ and $v_{2}, \mathrm{~m}$.

Results of the research (Figure 3.7) indicate that bluntness of the tip is characterizing with equal tendency of changes in ranges of cutting velocity 20 to $35 \mathrm{~m} \mathrm{~s}^{-1}$ and 35 to $50 \mathrm{~m} \mathrm{~s}^{-1}$, therefore it is possible to merge these ranges. Based on figure 3.7, permissible length of the cutting trajectory till critical bluntness period is $L_{1}=9779 \mathrm{~m}$ if cutting velocity $v_{1}=20 \mathrm{~m} \mathrm{~s}^{-1}$ and permissible length of the cutting trajectory till critical bluntness period is $L_{2}=13139 \mathrm{~m}$ if cutting velocity $v_{2}=50 \mathrm{~m} \mathrm{~s}^{-1}$. Consequently, constant $\psi$ is following (Equation 4.3):

$$
\psi_{v=20 \ldots 50}=-1 \cdot \frac{\ln 50-\ln 20}{\ln 13139-\ln 9779}=-3.060
$$

Value of coefficient $\psi$ is calculated analogically also the rest range of $v$ :

$$
\psi_{v=50 \ldots 75}=-1 \cdot \frac{\ln 75-\ln 50}{\ln 12026-\ln 13193}=4.378
$$

By inserting results in equation 4.2 and calculating equations of naturallogarithm, it is possible to obtain that values of constant $C$ are following:

$$
C_{v=20 \ldots 50}=e^{\ln 20+(-3.060) \cdot \ln 9779}=e^{\ln 50+(-3.060) \cdot \ln 13193}=1.233 \cdot 10^{-11}
$$




$$
C_{v=50 \ldots 75}=e^{\ln 50+4.378 \cdot \ln 13193}=e^{\ln 75+4.378 \cdot \ln 12026}=5.465 \cdot 10^{19}
$$

Consequently, based on equation 4.1, the Taylor equations corresponding to the range of the research are following:

$$
\begin{aligned}
& v_{20 \ldots 50} \cdot L^{-3.060}=1.233 \cdot 10^{-11} \\
& v_{50 \ldots .75} \cdot L^{4.378}=5.465 \cdot 10^{19}
\end{aligned}
$$

The equations (4.4 and 4.5) describe length of cutting trajectory (bluntness of the tip) only based on $v$, however, by carrying out an analysis of wood cutting processes it has been concluded that the rest of the main cutting regime parameters play a significant role as well. The impact of the rest of the parameters is described by the following replenished Taylor's equation:

$$
v \cdot L^{\psi} \cdot \gamma^{f} \cdot u_{z}^{\kappa} \cdot \varphi_{v i d}^{g}=C,
$$

where $\quad v$ - cutting velocity, $\mathrm{m} \mathrm{s}^{-1}$;

$L-$ length of cutting trajectory related to one tip, m;

$\gamma$ - rake angle of tip, degree;

$u_{z}$ - feed per tooth, mm;

$\varphi_{v i d}-$ mean angle between the direction of the cutting and feed movement, degree;

$\psi$ - a constant which depends on slope of the curve which depends on tool bluntness;

$f$ - coefficient which depends on rake angle of tip;

$\kappa$ - coefficient which depends on feed per tooth;

$g$ - coefficient which depends on mean angle between the direction of the cutting and feed movement;

$C-$ a constant which is equal to the naturallogarithm of intercept of the curve of the tool bluntness and the ordinate.

Every factor affecting bluntness of the tip changes $L$ by a certain value in respect to the $L$ as it was at the beginning of the critical bluntness period during the experiment $1 \quad\left(v=50 \mathrm{~m} \mathrm{~s}^{-1}, \quad \gamma=15\right.$ degree, $u_{z}=0.503 \mathrm{~mm}, \quad \varphi_{\text {vid }}=36.9$ degree) because one variable of each of 
the cutting regime parameters conform to the regime of this experiment. Therefore, in order to calculate values of the coefficients $f, \kappa$, and $g$ it is possible to use equations that are capable of calculating how many times $L$ changes in respect to the $L$ value observed during the experiment 1 :

$$
\begin{gathered}
f_{i}=-\psi \cdot \log _{\gamma_{i}} \frac{L_{\rho \gamma_{i}}}{L_{\rho \gamma_{0}}}, \\
\kappa_{i}=-\psi \cdot \log _{u_{z i}} \frac{L_{\rho u_{z i}}}{L_{\rho u_{z 0}}} \\
g_{i}=-\psi \cdot \log _{\varphi_{v i d}} \frac{L_{\rho \varphi_{v i d i}}}{L_{\rho \varphi_{v i d}}},
\end{gathered}
$$

where $f_{i}$ - coefficient which depends on rake angle of tip;

$\kappa_{i}$ - coefficient which depends on feed per tooth;

$g_{i}$ - coefficient which depends on mean angle between the direction of the cutting and feed movement; $\psi$ - a constant which depends on slope of the curve which depends on tool bluntness; $\gamma_{i}, u_{z i}, \varphi_{v i d i}$ - values of rake angle of tip (feed per tooth, mean angle between the direction of the cutting and feed movement); degree ( $\mathrm{mm}$, degree); $L_{\rho}$ - length of cutting trajectory related to one tip at beginning of critical bluntness period correspond to values of $\gamma_{i}, u_{z i}, \varphi_{\text {vid } i}, \mathrm{~m}$; $L_{\rho \gamma_{0}}, L_{\rho u_{z 0}}, L_{\rho \varphi_{v i d 0}}-$ length of cutting trajectory related to one tip at beginning of critical bluntness period correspond to values of variable cutting regime parameters in experiment $1, \mathrm{~m}$.

Both the angle $\gamma, u_{z}$ and angle $\varphi_{v i d}$ are linear impact on the bluntness of the tip which means that it is possible to determine coefficients $f$, $\kappa$, and $g$ values only in respect to their minimum and maximum boundaries. It is not necessary to calculate coefficients for the boundary values of the parameters conforming to the data of the experiment 1 as it may be concluded that their value is equal to 0 . Thus, calculations should be carried out only in respect to the maximum boundaries of the variable range, taking into account that 
coefficient $\psi$ value changes by changing the $v$ range. A summary of calculations for the constants and coefficients for the Taylor's equation is shown in table 2.

As a result, in order to predict length of the cutting trajectory that is the beginning of the critical bluntness period based on cutting velocity, rake angle of tip, feed per tooth and mean angle between the direction of the cutting and feed movement, it is possible to use the constants and coefficients shown in table 2 and the following equation that is obtained from equation 4.6:

$$
L=C^{\frac{1}{\psi}} \cdot v^{\frac{-1}{\psi}} \cdot \gamma^{\frac{-f}{\psi}} \cdot u_{z}^{\frac{-\kappa}{\psi}} \cdot \varphi_{v i d}^{\frac{-g}{\psi}} .
$$

The equation (4.10) shows the permissible length of cutting trajectory related to one tip of a ripsaw blade, therefore the obtained result must be multiplied by the actual amount of tips on the saw blade. In its turn, it is possible to apply equation 3.5 that is indicating the reading from the wattmeter connected to the electric motor of the cutting mechanisms in order to determine the electrical power value at the beginning of the critical bluntness period.

\section{CONCLUSIONS}

1. During the cutting process, bluntness of the tip (roundness radius of the cutting edge), the consumed electrical power and specific cutting work (force) are significantly dependent on the factorial parameters of the cutting regime - cutting velocity, rake angle of the tip, feed per tooth, mean angle between the direction of the cutting and feed movement - and length of the cutting trajectory. Roughness of the treated surface is significantly dependent on the rake angle of the cutter and length of the cutting trajectory (bluntness of the tip), while the mechanical cutting power is significantly dependent only on electrical power as its prediction model includes both electrical power and factorial parameters of the cutting regime.

2. Mechanical cutting power obtained from the cutting force measurements and electrical power obtained from the current amperage and voltage measurements is not equal. Electrical cutting power in longitudinal sawing of aspen wood is 1.11 to 1.34 times higher than the mechanical cutting power.

3. Bluntness of the tip causes increase in the specific cutting work (force) when the length of the cutting trajectory increases, thus this increase is equal to the assessment coefficient of the bluntness of the tip $a_{\rho}$, calculation of which is not only based on working time of the tip after 
sharpening, but also on cutting velocity, rake angle of the tip, feed per tooth and mean angle between the direction of the cutting and feed movement.

4. Electrical power consumed during the cutting process decreases by $32 \%$ if the cutting velocity is increased from 20 to $59 \mathrm{~m} \mathrm{~s}^{-1}$, by 17 to $42 \%$ if the rake angle of the tip is increased from 15 to 30 degrees, by $128 \%$ if feed per tooth is decreased from 1.005 to $0.471 \mathrm{~mm}$ and by $96 \%$ if the mean angle between the direction of the cutting and feed movement is decreased from 36.9 to 18.2 degrees.

5. The initial bluntness period of a single tip of a ripsaw blade based on the changes in the roundness radius of the cutting edge is up to 1500 meters of the cutting trajectory and it is not significantly dependent on the factorial parameters of the cutting regime.

6. The beginning boundary of the critical bluntness period of a single tip of a ripsaw blade may change from 9700 to $16900 \mathrm{~m}$ depending on the factorial parameters of the cutting regime. The beginning boundary of the critical bluntness period increases by $35 \%$ if the cutting velocity is increased from 20 to $59 \mathrm{~m} \mathrm{~s}^{-1}$, by $27 \%$ if the rake angle of the tip is increased from 15 to 30 degrees, by $32 \%$ if feed per tooth is decreased from 1.005 to $0.503 \mathrm{~mm}$ and by $28 \%$ if the mean angle between the direction of the cutting and feed movement is decreased from 36.9 to 18.2 degrees.

7. Constants of Taylor's equation for prediction bluntness of the tip are $\psi=-3.060$ and $C=1.233 \cdot 10^{-11}$, if cutting velocity is in the range of 20 to $50 \mathrm{~m} \mathrm{~s}^{-1}$, while these constants are $\psi=4.378$ and $C=5.465 \cdot 10^{19}$, if cutting velocity is in the range of 50 to $75 \mathrm{~m} \mathrm{~s}^{-1}$ in longitudinal sawing of aspen wood.

8. The developed method for prediction bluntness of the tip and electrical power consumption by taking into account the cutting velocity, rake angle of the tip, feed per tooth, mean angle between the direction of the cutting and feed movement and length of the cutting trajectory shows a significant credibility level.

\section{SUGGESTIONS}

1. The following cutting regime with the following parameters should be used in longitudinal sawing of aspen wood in order to increase the length of the cutting trajectory until the critical bluntness period and till $29 \%$ decrease power and thus the related expenses consumed during the cutting process: cutting speed $59 \mathrm{~m} \mathrm{~s}^{-1}$, rake angel of the 
tip 30 degrees, feed per tooth $0.471 \mathrm{~mm}$, while the mean angle between the direction of the cutting and feed movement should be as little as possible that may be achieved by placing the materials to be sawed as close as possible to the periphery of the ripsaw blade. Other cutting regime parameters should be determined based on the aforementioned values.

2. The improved Taylor's equations as well as its constants and coefficients should be used in order to determine the length of the cutting trajectory of period between sharpening of the tips, while the following regression equation should be used to determine the length of the cutting trajectory $L, \mathrm{~m}$, respective value of electrical power $N_{e l}, \mathrm{~W}$, based on cutting velocity $v, \mathrm{~m} \mathrm{~s}^{-1}$, rake angle of the tip $\gamma$, degree, feed per tooth $u_{z}, \mathrm{~mm}$, mean angle between the direction of the cutting and feed movement $\varphi_{v i d}$, degree: $N_{e l}=1.072 \cdot 10^{-2} \cdot L-$ $-6.750 \cdot v-5.989 \cdot 10^{-2} \cdot v^{2}-4.284 \cdot \gamma-230.849 \cdot u_{z}+259.407 \cdot u_{z}^{2}+$ $+3.029 \cdot \varphi_{\text {vid }}-2.235$.

3. The duration control of the period between sharpening of tips should be carried out based on the results from the wattmeter installed on the electric motor of the cutting mechanism that may be connected to the electronic information system that is sending a notification regarding the beginning of the critical bluntness period when the calculated value of electrical power is reached. 